\title{
The glaciovolcanic evolution of the Copahue volcano, Andean Southern Volcanic Zone, Argentina-Chile
}

\author{
Alejandro D. Báez ${ }^{\mathrm{a}, \mathrm{b}, *}$, Walter Báez ${ }^{\mathrm{c}}$, Alberto T. Caselli ${ }^{\mathrm{a}, \mathrm{b}}$, Mateo A. Martini ${ }^{\mathrm{d}, \mathrm{e}, \mathrm{f}}$, Carlos A. Sommer ${ }^{\mathrm{g}}$ \\ a Universidad Nacional de Río Negro, Instituto de Investigación en Paleobiología y Geología, Río Negro, Argentina

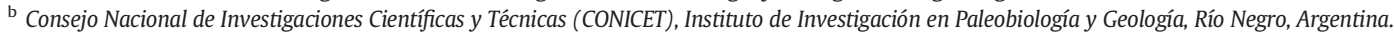 \\ c IBIGEO (Universidad Nacional de Salta-CONICET), Av. Bolivia 5150, A4400FVY Salta, Argentina \\ ${ }^{\mathrm{d}}$ Núcleo Milenio Paleoclima, Universidad de Chile, Santiago, Chile \\ e Instituto de Geografí, Pontificia Universidad Católica de Chile, Santiago, Chile \\ ${ }^{\mathrm{f}}$ Centro de Investigaciones en Ciencias de la Tierra (CICTERRA, CONICET-Facultad de Ciencias Exactas, Físicas y Naturales, UNC), Córdoba, Argentina \\ ${ }^{g}$ Universidade Federal do Rio Grande do Sul (UFRGS), Av. Bento Gonçalves 9500, 15001, 91501-970 Porto Alegre, Brazil
}

\section{A R T I C L E I N F O}

\section{Article history:}

Received 10 October 2019

Received in revised form 23 March 2020

Accepted 23 March 2020

Available online 25 March 2020

\section{Keywords:}

Glaciovolcanism

Volcano-ice interaction

Caviahue-Copahue volcanic complex

Late Pleistocene

\begin{abstract}
A B S T R A C T
Glaciovolcanism produces distinctive features that are useful paleoclimate proxies for the distribution of past ice sheets and glacier extent. The Copahue volcano located in the Andean Southern Volcanic Zone, Argentina-Chile, is an active composite volcano known to have glaciovolcanic features such as lava bodies with glassy margins and anomalous cooling fractures. However, the emplacement conditions of these products and the influence of Pleistocene glaciations on the evolution of the Copahue volcano remains poorly understood. In this contribution, we propose a model for glaciovolcanic evolution of the Copahue volcano based on the analysis, interpretation, and mapping of its products. Ten lithofacies are described on the eastern flank of Copahue volcano exhibiting several examples of glaciovolcanism. The evolution of the Copahue volcano can be divided into two main sequences: the Ancient Sequence (S1) and the Young Sequence (S2), separated by a major erosive phase. The S1 (early-middle Pleistocene-late Pleistocene) consists of an initial subaerial effusive stage followed by a major glaciovolcanic stage, during which a thick ice cap existed and the edifice grew beneath an englacial lake with the eventual formation of a lava-fed delta. The S2 (late Pleistocene-Present) is defined by mainly effusive activity during periods of glacial advance and retreat recorded by an alternation of unconfined subaerial lavas and ice-confined lavas. The evolution of the Copahue volcano therefore indicates two glaciations in the Copahue-Caviahue area during the late Pleistocene, in contrast to a single glaciation. Based on the glacial history in the area we associate the first glaciation with the end of Marine Isotope Stage 3 (57-29 ka) and/or the Last Glacial Maximum period (26.5-19.0 ka), and the second less-extensive glacial period with the Antarctic Cold Reversal (14.5-12.9 ka).
\end{abstract}

(C) 2020 Elsevier B.V. All rights reserved.

\section{Introduction}

Glaciovolcanism is defined as all interactions between volcanic activity and ice in all its forms, including meltwater derived from volcanic heating (Smellie, 2006; Edwards et al., 2015; Smellie and Edwards, 2016). This type of volcanism produces distinctive diagnostic features, including landforms (e.g. Hickson, 2000; Edwards and Russell, 2002; Pedersen and Grosse, 2014; Russell et al., 2014; Smellie, 2013), lithofacies (e.g. Loughlin, 2002; Edwards et al., 2009; Lachowycz et al., 2015; Cole et al., 2018) and fracture patterns in lavas (e.g. Lescinsky and Fink, 2000; Spörli and Rowland, 2006; Lodge and Lescinsky, 2009; Forbes et al., 2012; Forbes et al., 2014a; Forbes et al., 2014b).

\footnotetext{
* Corresponding author at: Universidad Nacional de Río Negro, Instituto de Investigación en Paleobiología y Geología, Río Negro, Argentina.

E-mail address: adbaez@unrn.edu.ar (A.D. Báez).
}

Although the classic case studies are from the glaciovolcanic provinces located in Antarctica, Iceland and British Columbia (Canada), in recent years more research has highlighted glaciovolcanism around the world (Edwards et al., 2015), including on volcanoes in mid-latitude continental arcs (e.g. Mee et al., 2006; Conway et al., 2015; Lachowycz et al., 2015; Cole et al., 2018). This expansion of interest is mainly due to the recognition of glaciovolcanic deposits as useful paleoclimate proxies since they provide valuable information about the extent, thickness, and age of ice sheets (Edwards et al., 2015).

The Copahue volcano is an active composite volcano in the southern Argentine-Chilean Andes, where glaciovolcanic features such as lava bodies with glassy margins and cooling fractures had been grouped in a "syn-glacial stage" (Bermúdez and Delpino, 1999; Melnick et al., 2006; Sruoga and Consoli, 2011a). However, the emplacement conditions of these features and the influence of the Pleistocene glaciations on the evolution of the Copahue volcano remains poorly understood. 
In this contribution, we propose a model for edifice evolution closely linked to glaciovolcanic processes at the Copahue volcano based on the analysis, interpretation, and mapping of its products. Consequently, a new stratigraphic scheme is presented and we discuss the paleoclimatic implications that arise from the novel data presented.

\section{Geological setting and glacial history}

\subsection{Geological setting}

Copahue is a composite volcano of intermediate composition located on the border between Argentina and Chile $\left(37.86^{\circ} \mathrm{S}\right.$, $71.17^{\circ} \mathrm{W}$ ), in the central sector of the Southern Volcanic Zone (SVZ) of the Andes (Fig. 1). The Copahue volcano lies on the western rim of the Caviahue caldera, forming the Caviahue-Copahue Volcanic Complex (CCVC), which has been active at least since Pliocene (Pesce, 1989; Linares et al., 1999). The edifice shows an elongated shape with nine summit craters aligned in SW-NE direction, the easternmost of which is currently active (Sruoga and Consoli, 2011a; Caselli et al., 2016a). The age of the Copahue volcano and the duration of volcanism is not well constrained. Classic $\mathrm{K}-\mathrm{Ar}$ ages obtained by Linares et al. (1999) vary between $1.23 \pm 0.09$ Ma and $0.76 \pm$ $0.07 \mathrm{Ma}$. However, other authors obtained $\mathrm{K}-\mathrm{Ar}$ ages between 0.6 $\pm 0.4 \mathrm{Ma}$ and $0.4 \pm 0.3 \mathrm{Ma}$ for units that predate Copahue volcano (Muñoz Bravo et al., 1989; Polanco, 2003). Most recent ${ }^{40} \mathrm{Ar} /{ }^{39} \mathrm{Ar}$ dating of the pre-Copahue Las Mellizas volcanic sequence yielded an age of $125 \mathrm{ka}$ (Sruoga and Consoli, 2011b). This evidence implies that de Copahue volcano could be substantially younger than the ages obtained by Linares et al. (1999).

Previous work proposed several stratigraphic schemes for the CVCC (Pesce, 1989; Delpino and Bermúdez, 1993; Polanco, 2003; Varekamp et al., 2006). The most recent scheme, based on field relations and temporal relationship with glaciations, divides the evolution of Copahue into three stages: 1) a pre-glacial stage comprising a succession of up to $1000 \mathrm{~m}$ of lavas and minor deposits of pyroclastic flows with evidence of glacial erosion, 2) a syn-glacial stage comprising lavas with evidence of interaction with water/ice assigned to sub-glacial eruptions produced in one or more glacial periods during the last $0.7 \mathrm{Ma}$, and 3 ) a post-glacial stage mainly comprising lava flows without evidence of glacial erosion (Melnick et al., 2006; Sruoga and Consoli, 2011a). In historical times, the volcano has had at least 11 phreatic and phreatomagmatic eruptive episodes in the last 270 years (PetitBreuilh, 2004; Caselli et al., 2016a).

\subsection{Late Pleistocene glacial history in Patagonia}

The last Pleistocene glaciation occurred between 110 and 11.7 ka with the coolest period of the last glaciation, referred to as the Last Glacial Maximum (LGM), occurring during 26.5-19.0 ka (Clark et al., 2009). During the late Pleistocene, glaciers expanded in Patagonia generating a big ice sheet that extended from $\sim 36-38^{\circ} \mathrm{S}$ in northern Patagonia to $\sim 55^{\circ} \mathrm{S}$ in Tierra del Fuego (Hulton et al., 2002). Outlet glaciers that flowed from the big ice sheet record their maximum expansion during the LGM (Denton et al., 1999; Darvill et al., 2016) or even before, during the Marine Isotope Stage 3 (57-29 ka) (Darvill et al., 2015; Hein et al., 2017). After this, the LGM glaciers started to retreat, generating most of the present-day Patagonian lakes. During the deglaciation renewed glacial advances occurred but were less extensive than those from the LGM. New evidence suggests that these late glacial advances occurred during the Antarctic Cold Reversal (ACR, 14.5-12.9 ka) (Strelin et al., 2011; García et al., 2012; Sagredo et al., 2018), a cooling period during the deglaciations that was first discovered in Antarctic ice cores.

Near the Copahue volcano, the chronology of the glacial activity during the late Pleistocene is fragmentary. Pioneer work (Groeber, 1925) identified two glaciations in this area during the Pleistocene. Radiocarbon dating on glaciofluvial deposits near the Copahue volcano, attributed to the oldest glacial advance, yield an age of $30 \mathrm{ka}$ (Bermúdez and Delpino, 1999). In contrast, González Díaz (2003, 2005) proposed a single glacial episode in this area characterized by the generation of an ice cap of 500-800 m thick, rejecting the existence of the youngest glaciation. However, all these authors agree that a thick ice cap entirely covered the Caviahue caldera during the maximum glacier expansion.

In the Maule area, $\sim 200 \mathrm{~km}$ northward of Copahue volcano, ${ }^{40} \mathrm{Ar} /{ }^{39} \mathrm{Ar}$ age of lava flows at $2200 \mathrm{~m}$ a.s.l. indicates that at $26-23 \mathrm{ka}$ the area was not glaciated, and that glaciers did not expand afterward. In the Rucachoroi valley, $150 \mathrm{~km}$ southward from the Copahue volcano, Zech et al. (2017) established a glacial chronology based on 16 cosmogenic ${ }^{10} \mathrm{Be}$ surface exposure dating of erratic boulders deposited in moraine crests. The results show that a series of progressively lessextensive glacier expansions occurred at $\sim 45-40 \mathrm{ka}, \sim 21-18 \mathrm{ka}$, and 15-14 ka.

\section{Methods}

Fieldwork was carried out during the austral summer of 2017, 2018 and 2019, including conventional stratigraphic logging, detailed description of the lithofacies, collection of samples for petrographic and geochemical analysis, and geological mapping. The geological map was made from field observations based on lithostratigraphic criteria and field relationships supported by satellite images. In order to avoid genetic connotations a non-genetic nomenclature was adopted to identify each lithostratigraphic unit.

The lithofacies code is composed of a primary lithologic descriptor in capital letter, accompanied by a secondary descriptor in a lowercase letter that represents a distinctive feature. The volcaniclastic lithofacies (composed of fragments originated by primary volcanic fragmentation and transported/deposited by processes directly related to eruptions) are described using the terminology proposed by White and Houghton (2006). The sedimentary lithofacies (composed mostly of fragments formed or reshaped during transport or depositional processes not directly related to eruptions) are broadly mapped but not analyzed in detail.

The petrographic analysis consisted of the description of thin sections of selected samples. Whole rock geochemical analyses were made on selected samples, and the results compared with published data. Major element concentrations were determined by ICP-ES method at ACME Analytical Laboratories Ltd. (Canada) and by FUS-ICP method at ActLabs laboratory (Canada).

Throughout this contribution, we use the term "subglacial eruption" strictly for eruptions beneath ice. For subaerial lavas downslope constrained by ice we use the term "ice-confined lavas". These lavas are called "ice-dammed lavas" when the lavas are impounded but their movement is not totally restricted and "icebounded lavas" or "ridge-forming lavas" when the lavas are laterally restricted by adjacent glaciers. For a more detailed discussion of glaciovolcanic terms see the glossary in Smellie and Edwards (2016). The cooling fracture terminology is based on previous work (Lescinsky and Fink, 2000; Lodge and Lescinsky, 2009; Forbes et al., 2012; Forbes et al., 2014b; Conway et al., 2015; Smellie and Edwards, 2016; see Supplementary material).

\section{Geological mapping}

We have compiled a 1:40000 scale geological map of the eastern flank of the Copahue volcano based on lithostratigraphic criteria and field relationships (Fig. 2). The mapped area is delimited by the coordinates $37.821^{\circ} \mathrm{S}-37.887^{\circ} \mathrm{S}$ and $71.106^{\circ} \mathrm{W}-71.165^{\circ} \mathrm{W}$, including the currently active crater. The distribution of pre-Copahue units is based on Melnick et al. (2006). It should be noted that the similarity of Unit A with the top lavas of the underlying Las Mellizas Volcanic Sequence 


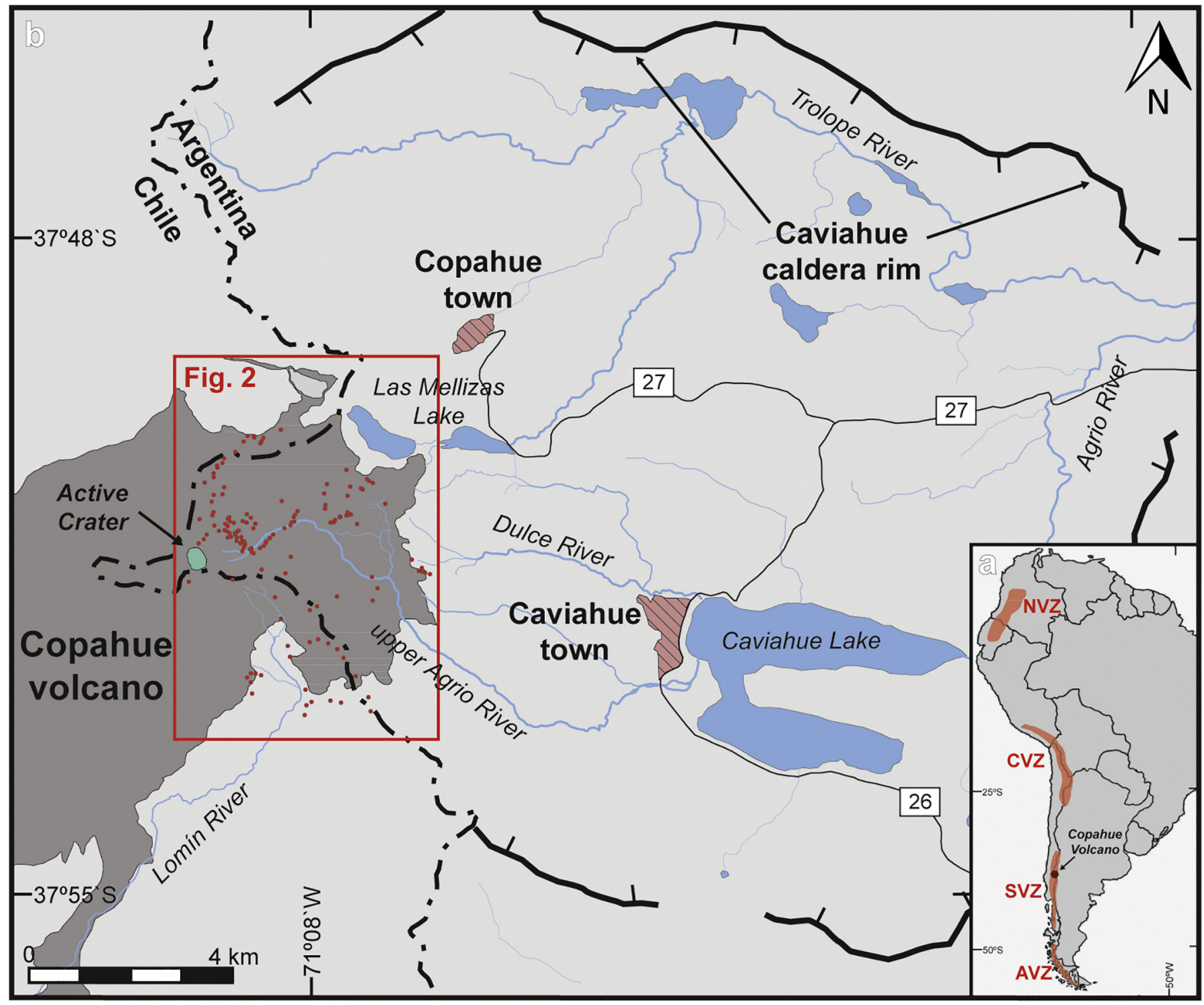

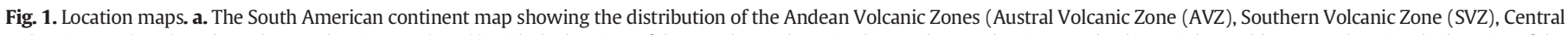

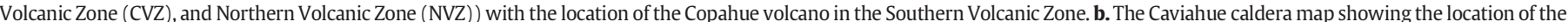

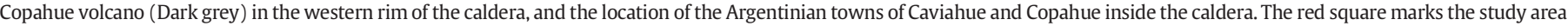
in Fig. 2 and the red point marks field works stations. (For interpretation of the references to colour in this figure legend, the reader is referred to the web version of this article.)

makes the boundary between both units tentative, as was highlighted by Sruoga and Consoli (2011a).

The evolution of Copahue volcano can be divided into two main sequences: i) the oldest Ancient Sequence (S1) constituted by Unit A, Unit $B$, and Unit $C$, representing a large part of the volume of the volcanic edifice. The $\mathrm{S} 1$ is strongly affected by a major erosive phase that formed the glacial cirques located in the Pucón Mahuida area (Fig. 3) and in the northeast flank of the volcano (Fig. 4). This major erosive feature marks the end of S1 and the onset of renewed volcanism; ii) the Young Sequence (S2) constitutes units D, E, F, G, H and I, which are not affected by the major erosive phase; however, some units show evidence of later glacial activity. The S2 include the volcaniclastic deposits associated with historical eruptions of the Copahue volcano (Unit I). Most of the units that form part of the S2 are associated with vents presumably located in or near the active crater. However, minor volumes of lavas related to flank eruptions (Unit $\mathrm{H}$ ) are also present. The stratigraphic relationships between all these units are clear, except in the case of Unit E, which only shows contacts with the underlying Unit A.
We consider Unit $\mathrm{E}$ as coeval to Unit $\mathrm{D}$ following the stratigraphic interpretations of Melnick et al. (2006).

\section{Geochemistry and petrography}

Lavas of the Copahue volcano are intermediate in composition, ranging from basaltic-andesitic to trachyandesitic (Fig. 5a; 54-59 wt\% $\mathrm{SiO}_{2}$ and $~ 5.3-6.5 \mathrm{wt} \% \mathrm{Na}_{2} \mathrm{O}+\mathrm{K}_{2} \mathrm{O}$ ) with medium to high-K calc-alkaline affinities (Fig. 5b). Lavas of Copahue show a consistent modal composition mainly represented by plagioclase and clinopyroxene, with subordinate olivine, orthopyroxene, and opaques. However, textural variations, mainly in the grain size of the groundmass due to different cooling rates, are observed in the lavas of the Copahue Volcano.

In hand sample, these lavas have a porphyritic to glomeroporphyritic texture with phenocrysts of plagioclase and clinopyroxene in an aphanitic groundmass that varies from grey to black according to the degree of crystallinity. 


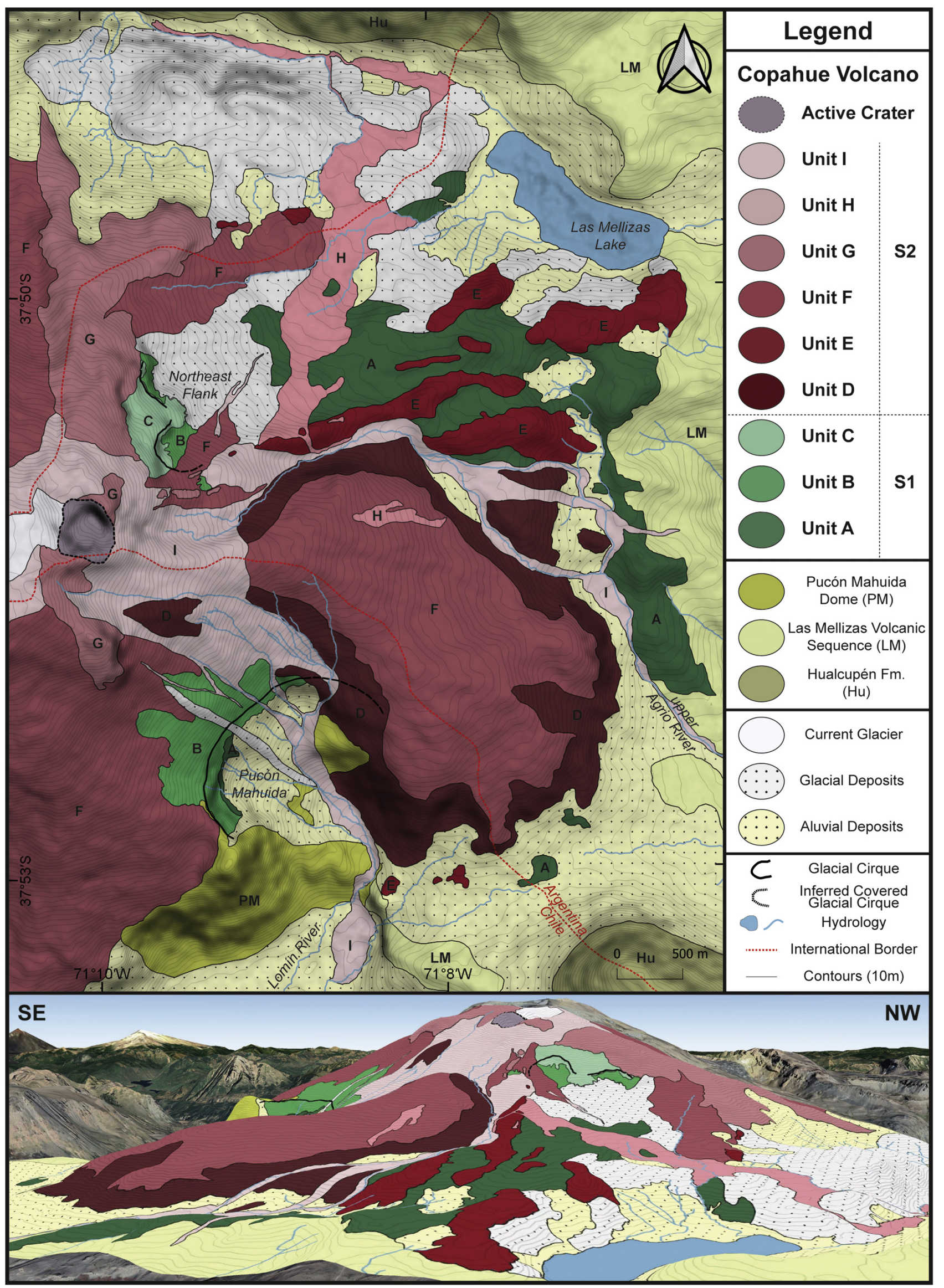




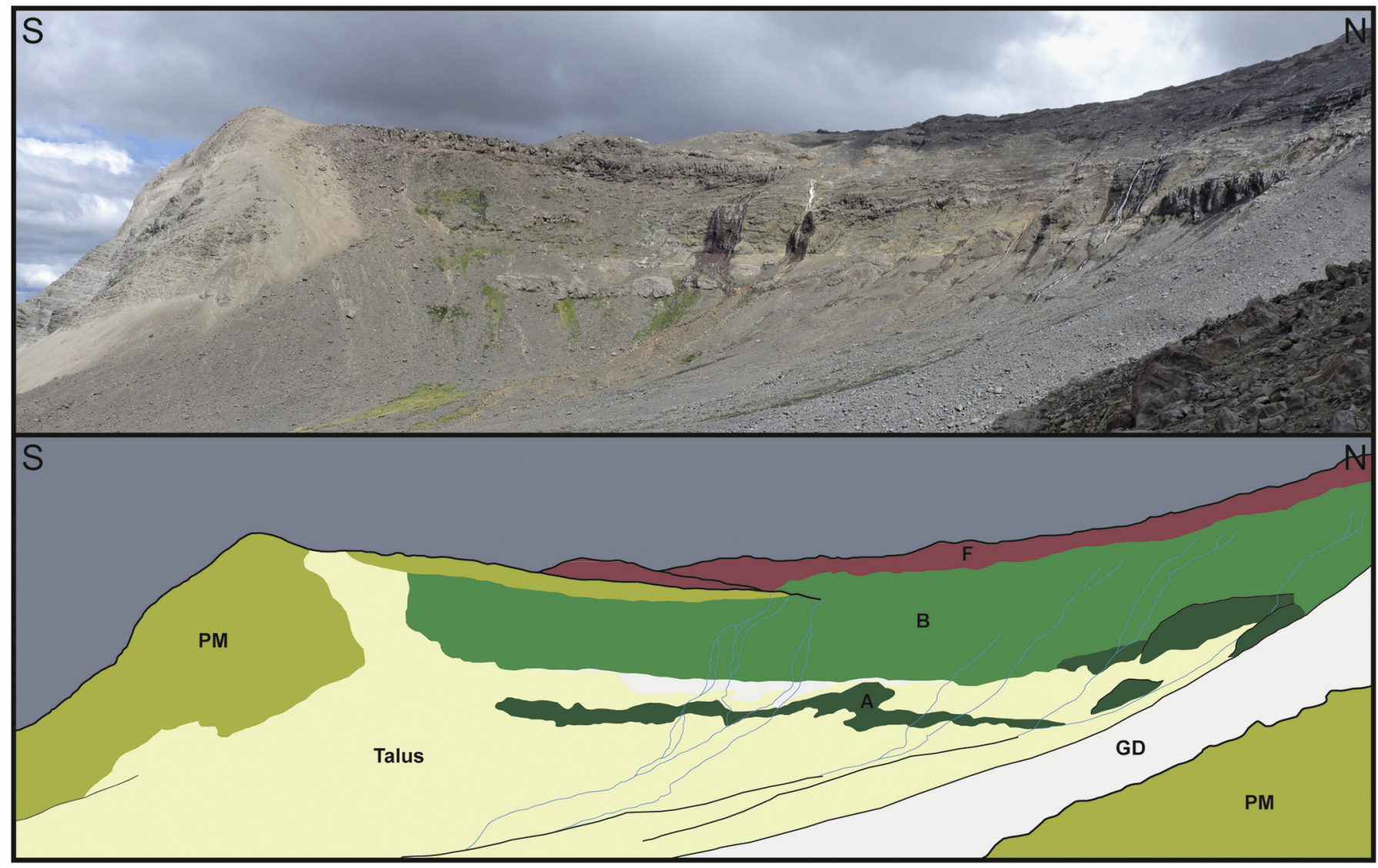

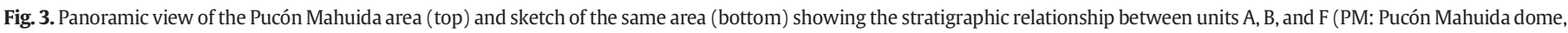
GD: Glacial deposits). View direction to the west.

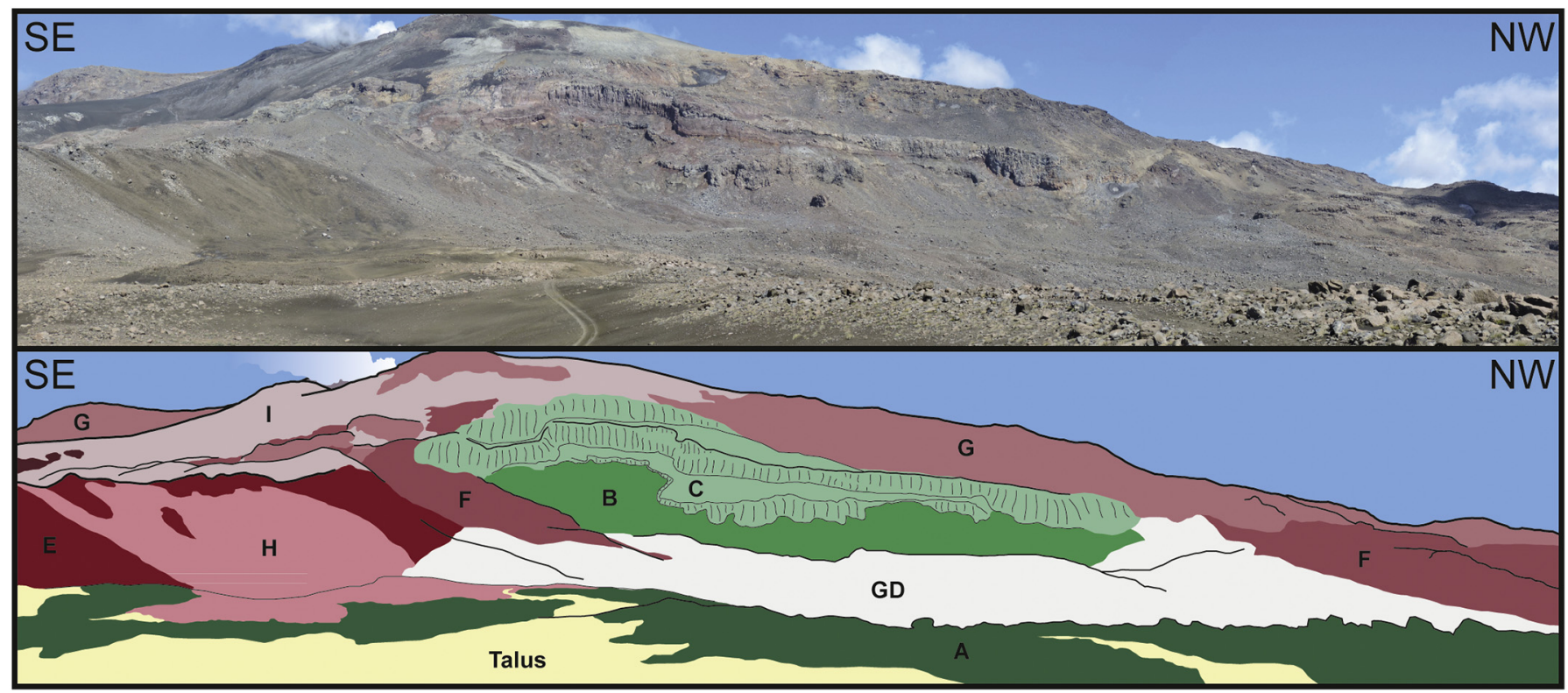

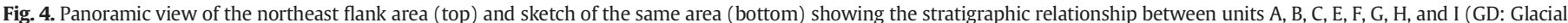
deposits). View direction to the southwest.

In thin section, plagioclase, pyroxene, olivine, and opaque microphenocrysts are also observed. The groundmass varies from microcrystalline with felty to trachytic textures in the most crystalline lavas, to hypocrystalline to cryptocrystalline (the result of devitrification?) in lavas that cooled rapidly (see Supplementary material).

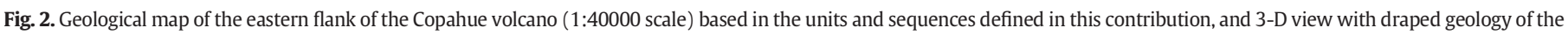
same area (bottom; view direction to the southwest). 

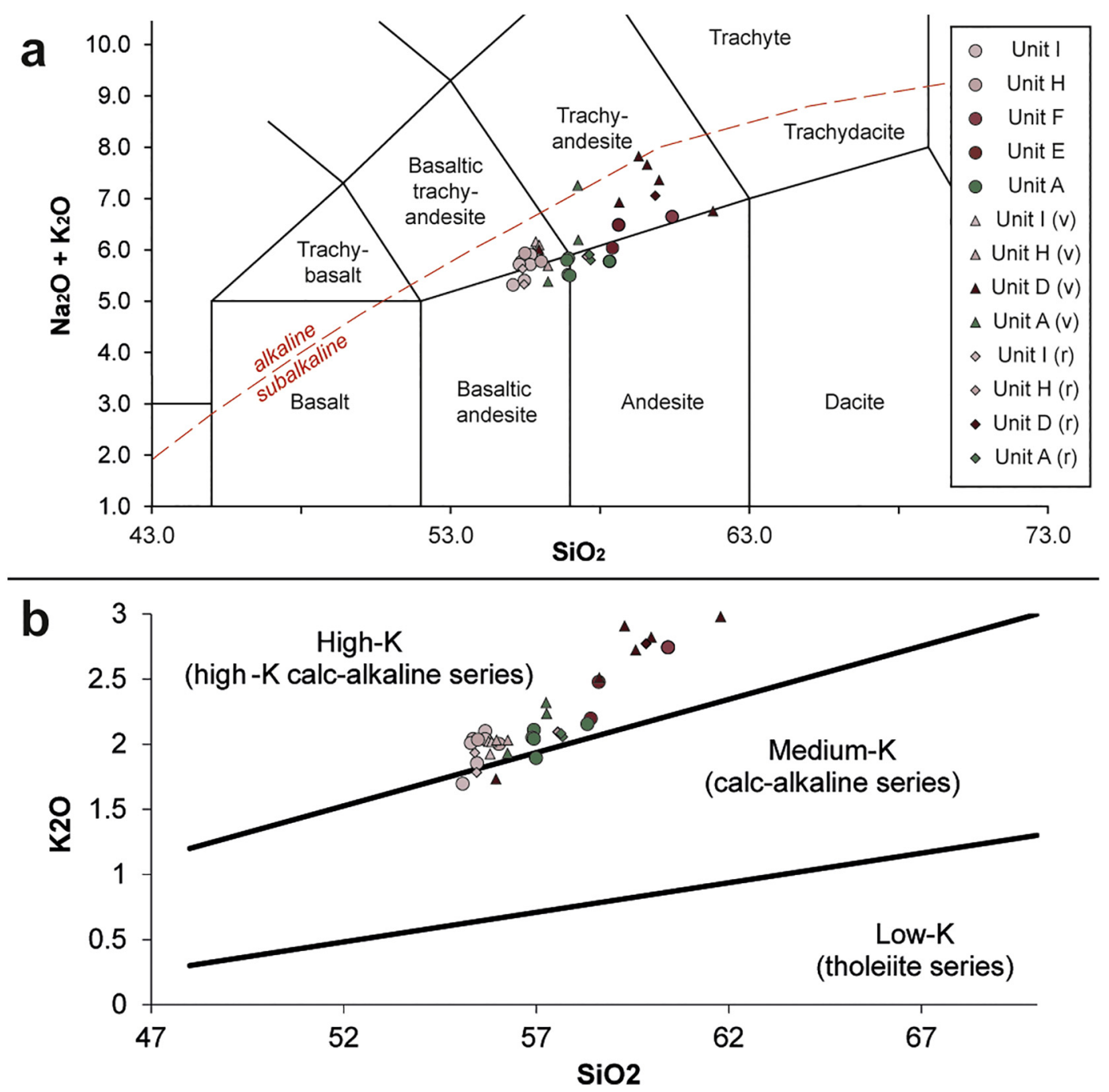

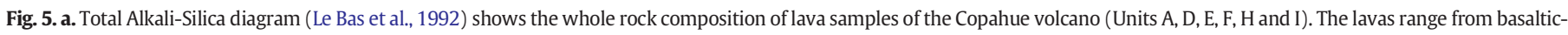

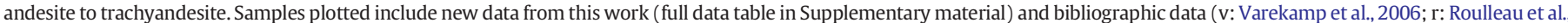

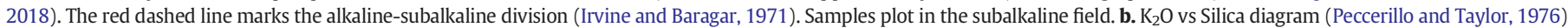

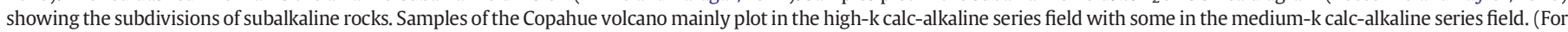
interpretation of the references to colour in this figure legend, the reader is referred to the web version of this article.)

\section{Lithofacies and units descriptions}

\subsection{Lithofacies classification}

We identified 10 different lithofacies at the eastern flank of Copahue volcano. Their codes, occurrences, descriptions, and interpretations are summarized in Table 1 . Three representative stratigraphic logs show the main lithofacies associations present in the edifice (Fig. 6).

\subsection{Unit A}

The oldest Unit A is mainly exposed in the area between the upper Agrio River and the Las Mellizas Lake covering an area of $\sim 2.5 \mathrm{~km}^{2}$, although smaller outcrops are in the southern sector of the study area. A maximum thickness up to $50 \mathrm{~m}$ is observed in the easternmost outcrops where the succession is exposed in walls generated by erosion. This unit comprises a succession of massive lavas ( $\mathrm{CL}$ ) that commonly have orange altered surfaces. Lavas of this unit are strongly polished and striated due to glacial abrasion (Fig. 7a).

\subsection{Unit B}

Unit B overlies the Unit A, although the contacts between them are mostly obscured. This unit is strongly eroded by glacial activity and shows its best exposures on the Pucón Mahuida and Northeast Flank cirques, reaching thicknesses of $\sim 200 \mathrm{~m}$ and $\sim 100 \mathrm{~m}$, respectively. The base of Unit B is only exposed in the western sector of Pucón Mahuida cirque. This is represented by a pillow lava ( $\mathrm{pL}$ ) succession deposited over diamictite deposits showing a peperitic contact (Fig. 7b,c). Pillow lavas are dark grey in colour and $\sim 15 \mathrm{~m}$ thick. Individual pillows are $<1 \mathrm{~m}$ wide and have highly vesiculated cores, glassy rims and welldeveloped radial jointing (Fig. 7d). Some show contraction cracks and locally an interstitial palagonitised pillow-fragment bearing tuff breccia matrix is present.

Above the pillow lavas there is a succession of tuff breccias dominated by clasts of pillow-fragment (pTB) interbedded with irregular massive lavas. This has distinctive yellowish chaotic outcrop appearance (Fig. 7e). The Northeast Flank outcrop presents a covered base and begins directly with this lithofacies. The pTB facies is monomict, poorly sorted and mainly matrix-supported and is composed of a yellow to orange (locally red) palagonitised lapilli-ash size matrix supporting clasts 
Table 1

Summary codes, occurrences, descriptions, and interpretations of lithofacies of the eastern flank of Copahue volcano.

\begin{tabular}{|c|c|c|c|c|c|}
\hline Lithofacies & & Code & Occurrence & Description & Interpretation \\
\hline \multirow[t]{4}{*}{ Lavas } & Coherent lava & $\mathrm{cL}$ & A, C, D, F, H & $\begin{array}{l}\text { Subhorizontal grey massive lava with porphyric to } \\
\text { glomeroporphyric texture with phenocrysts of plagioclase } \\
\text { and clinopyroxene in an aphanitic groundmass. Commonly } \\
\text { present orange altered surfaces. The least eroded preserve } \\
\text { basal, surface, and front auto-breccias. }\end{array}$ & $\begin{array}{l}\text { Subaerial non-confined lava flow without interaction } \\
\text { with ice/water. }\end{array}$ \\
\hline & Pillow Lava & $\mathrm{pL}$ & B & $\begin{array}{l}\text { Dark grey pillow lavas succession up to } 15 \text { m thick. } \\
\text { Individual pillows are }<1 \mathrm{~m} \text { wide and have highly } \\
\text { vesiculated cores, vitric rims and well-developed radial } \\
\text { jointing. Superficially show contraction cracks and locally } \\
\text { present interstitial palagonitised pillow fragment-bearing } \\
\text { tuff breccia matrix. }\end{array}$ & Subaqueous lava emplaced within englacial lake. \\
\hline & Fractured Lava & $\mathrm{fL}$ & $\mathrm{D}, \mathrm{E}, \mathrm{G}$ & $\begin{array}{l}\text { Dark lava with pervasive cooling fracture systems with } \\
\text { characteristic variations in the orientation of the fractures. } \\
\text { Present a porphyric texture with phenocrysts of plagioclase } \\
\text { and clinopyroxene in an aphanitic hipocrystalline } \\
\text { groundmass. }\end{array}$ & Lava flow cooled rapidly due to interaction with ice. \\
\hline & Clastogenic Lava & $\operatorname{cgL}$ & $\mathrm{C}$ & $\begin{array}{l}\text { Reddish welded clastogenic lavas formed by a red (black in } \\
\text { the fresh face) domain with smooth surfaces that include } \\
\text { grey vesicular lenses that are flattened and stretched. }\end{array}$ & $\begin{array}{l}\text { Subaerial vent-proximal clastogenic lava flow fed by a } \\
\text { lava-fountain eruption. }\end{array}$ \\
\hline \multirow[t]{6}{*}{ Volcaniclastic } & $\begin{array}{l}\text { Pillow } \\
\text { fragment-bearing } \\
\text { tuff breccia }\end{array}$ & pTB & B & $\begin{array}{l}\text { Yellowish tuff breccia dominated by clasts of } \\
\text { pillow-fragment. Massive at the base to stratified on the } \\
\text { top. Monomict, poorly sorted and mainly matrix-supported } \\
\text { and composed by a yellow to orange (locally red) } \\
\text { palagonitised lapilli-ash size matrix and clasts of angular } \\
\text { pillow fragments of }<50 \mathrm{~cm} \text { in size. Interbedded with } \\
\text { irregular dark grey massive lavas. }\end{array}$ & $\begin{array}{l}\text { Subaqueous gravitational collapse of pillow lava } \\
\text { accumulation and re-sedimentation in foreset position of } \\
\text { a lava-fed delta. }\end{array}$ \\
\hline & Bedded lapilli tuff & bLT & $\mathrm{D}, \mathrm{G}$ & $\begin{array}{l}\text { Planar bedded grey to reddish lapilli tuff with beds defined } \\
\text { by grain-size variation and in some cases strongly } \\
\text { deformed by large-scale slumps. Lapilli tuff is mainly } \\
\text { matrix-supported, moderately sorted, composed by } \\
\text { lapilli-size angular clast of dark grey lavas in an ash-size } \\
\text { matrix. Other volcanic lithics are also present but not } \\
\text { abundant. Thin, well-sorted clast-supported lapilli-size } \\
\text { beds are also present and can contain block-size fragments } \\
\text { even up to } 30 \mathrm{~cm} \text {. }\end{array}$ & $\begin{array}{l}\text { Syn-eruptive volcaniclastic deposits emplaced by } \\
\text { meltwater drainage streams. }\end{array}$ \\
\hline & $\begin{array}{l}\text { Laminated lapilli } \\
\text { tuff }\end{array}$ & ILT & I & $\begin{array}{l}\text { Laminated lapilli tuff up to } \sim 3 \mathrm{~m} \text { thick. The stratification is } \\
\text { parallel planar with } 1-5 \mathrm{~cm} \text { thick beds. Fragments are } \\
\text { mainly lapilli-size }(<5 \mathrm{~cm}) \text { dark grey to brown vesicular } \\
\text { scoria with minor, generally smaller, volcanic lithic } \\
\text { supported in an ash-size matrix. }\end{array}$ & $\begin{array}{l}\text { Pyroclastic surge deposits associated with unidentified } \\
\text { historical eruption. }\end{array}$ \\
\hline & Massive lapilli tuff & mLT & I & $\begin{array}{l}\text { Light grey to whitish massive lapilli tuff that reaches up to } \\
55 \mathrm{~cm} \text { thick. Clast-supported and polymict, formed by } \\
\text { poorly sorted fine ash to fine lapilli-sized fragments } \\
\text { predominantly lithics. The lithics comprise white } \\
\text { sub-rounded fragments of amorphous silica and } \\
\text { grey-greenish spherical fragments of sulfur. Juvenile } \\
\text { fragments are scarce and exhibit blocky or vesicular } \\
\text { textures. }\end{array}$ & $\begin{array}{l}\text { Volcaniclastic deposits associated to historical recent } \\
\text { eruption. Previously interpreted either as products of } \\
\text { lahar generated during 1992-1995 eruptive cycle } \\
\text { (Delpino and Bermúdez, 1993) or as pyroclastic density } \\
\text { current deposit emplaced during } 2000 \text { eruption (Balbis } \\
\text { et al., 2016) }\end{array}$ \\
\hline & $\begin{array}{l}\text { Unconsolidated } \\
\text { Lapilli }\end{array}$ & uLP & I & $\begin{array}{l}\text { Unconsolidated dark grey to brown lapilli-sized vesicular } \\
\text { scoria. A minor amount of ash size components is also } \\
\text { present. }\end{array}$ & $\begin{array}{l}\text { Vent-proximal fall deposits ejected during the last } \\
\text { eruptive cycle 2012-2019 (Petrinovic et al., 2014; Caselli } \\
\text { et al., 2016b). }\end{array}$ \\
\hline & $\begin{array}{l}\text { Unconsolidated } \\
\text { Bombs and Blocks }\end{array}$ & $\mathrm{uB}$ & I & $\begin{array}{l}\text { Unconsolidated black vesiculated (moderately to highly) } \\
\text { bombs up to } 2 \mathrm{~m} \text {, and greyish highly altered block up to } 50 \\
\mathrm{~cm} \text { impregnated with sulfur. }\end{array}$ & $\begin{array}{l}\text { Vent-proximal ballistic fall deposits ejected during the } \\
\text { December 22nd, } 2012 \text { eruption (Petrinovic et al., 2014; } \\
\text { Caselli et al., 2016b). }\end{array}$ \\
\hline
\end{tabular}

of angular pillow fragments of $<50 \mathrm{~cm}$ in size. The pillow fragments have glassy rims; occasionally isolated individual pillows are preserved (Fig. 7f). The pTB facies is massive at the base to stratified on the top (Fig. $7 \mathrm{~g}$ ). The interbedded lavas are dark grey in colour and present irregular contacts with the pillow breccias. These lavas usually are not laterally continuous, forming irregular to tabular isolated bodies.

\subsection{Unit C}

Unit $\mathrm{C}$ is only exposed in the Northeast Flank cirque and presents a basal massive lava ( $\mathrm{CL}$ ) that gently dips to the northeast covering the underlying Unit B. A step in the cirque wall has formed as a result of differential erosion between these two units. This basal lava is mostly $\sim 5 \mathrm{~m}$ thick, although it exhibits thickness variations in distal sectors reaching up to $\sim 15 \mathrm{~m}$ without the presence of associated slope changes, increases in crystallinity, or any obvious preserved barrier.
Above the basal massive lava is a succession of clastogenic lavas (cgL) that forms a distinctive reddish wall of $\sim 20 \mathrm{~m}$ thick (Fig. $7 \mathrm{~h}$ ). These are welded clastogenic lavas formed by a red (black in the fresh face) domain with smooth surfaces that include grey vesicular lenses that are flattened and stretched.

Unit C culminates with a coherent lava similar to the basal lava showing the distal over-thickening as well. The upper lava flow was highly eroded by glacial activity showing polished surfaces and glacial striae.

\subsection{Unit $D$}

Unit D covers the previous units and was not affected by the major erosive phase. This unit was previously related to syn-glacial volcanism (Melnick et al., 2006; Sruoga and Consoli, 2011a) and is represented by a distinctive thick body with a flat top and steep fronts that covers an 


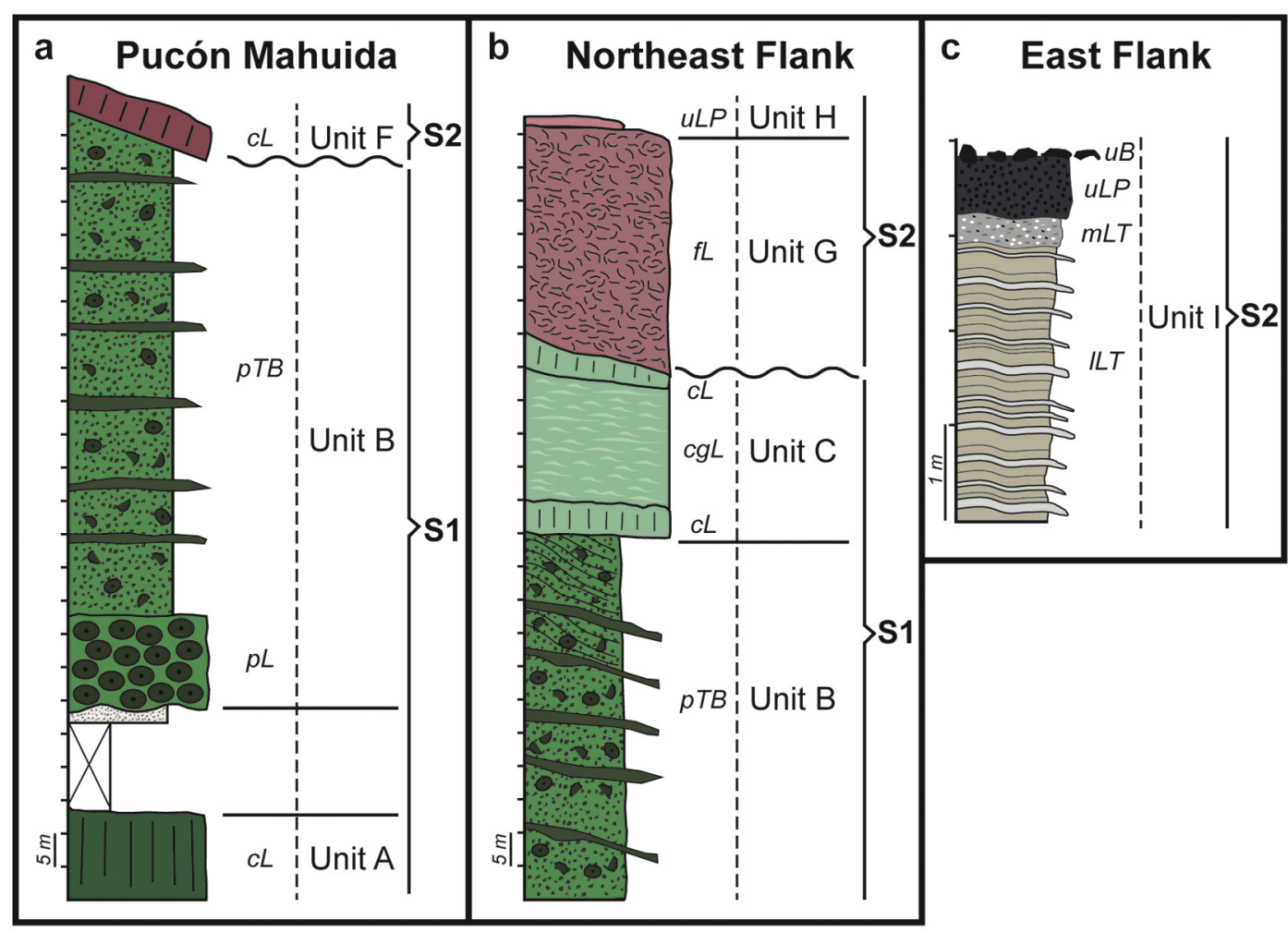

Fig. 6. Generalized representative stratigraphic logs showing the main lithofacies associations in: a. Pucón Mahuida area; b. northeast flank; and c. upper east flank.

area of ca. $6 \mathrm{~km}^{2}$ toward the east of the active crater. The fronts reach $100 \mathrm{~m}$ thick and are usually covered by debris fans formed by erosion. A maximum thickness of $200 \mathrm{~m}$ is estimated for the center of the body. The top of the body is covered by a thin layer of coherent lava flows of Unit F.

This unit is composed of a volcaniclastic basal section and a lava upper section (Fig. 8a). The basal section is an east-dipping succession composed of bedded grey-reddish lapilli tuff (bLT) strongly deformed by large-scale slumps best exposed in the upper Agrio River (Fig. 8b). The bLT facies is matrix-supported and moderately to poorly sorted, comprising lapilli-size angular fragments of dark grey vesicular lavas that vary from a few millimeters up to $5 \mathrm{~cm}$ in a reddish ash-size matrix. Other volcanic lithics are also present but are not abundant.

The upper section mainly consists of over-thickened lavas. In the margins of the body, the main lavas are black in colour and have pervasive fractures (fL). The fractures include fine-scale columnar joints, pseudo-pillow fractures, hackly fractures and concentric platy joints (Fig. 8c-e).

\subsection{Unit E}

This unit comprises a set of highly fractured dark lava bodies (fL) that show evidence of glacial erosion. Unit E crops out on the flanks, mainly in the area between the upper Agrio River and the Las Mellizas Lake where it overlies Unit A, covering $\sim 1.3 \mathrm{~km}^{2}$. Lavas grouped in Unit E were previously related to syn-glacial volcanism (Bermúdez and Delpino, 1999; Melnick et al., 2006; Sruoga and Consoli, 2011a). Most of the lavas included in this unit exhibit elongated shapes in plan although some have minor ratio aspect. The largest lava bodies reach $0.4 \mathrm{~km}^{2}$ and up to $25 \mathrm{~m}$ thick, and have margins covered by debris.

The lavas in Unit E show a wide range of fracture types including fine-scale columnar joints (Fig. 9a), hackly fractures, pseudo-pillow fractures (Fig. 9b,c) and curved platy joints (Fig. 9d). These lavas show characteristic variations in the orientation of the fractures, in some cases from vertical to horizontal. Some elongated lava bodies show a relatively thin margin (up to $\sim 1 \mathrm{~m}$ thick) with pseudo-pillow fractures, followed by a zone with fine platy joints parallel to the margin and finally a massive core (Fig. 9e).

\subsection{Unit F}

This unit includes relatively thin coherent lava flows with minor or no fractures (cL) and without evidence of confinement but strongly eroded by glacial activity. These lava flows are extended both to the north and south of the active crater and at the top of the body formed by the Unit D. Some of these last lavas come from fissures in the flank. Lavas of Unit F cover the previous erosive landforms such as glacial cirques and valleys (Fig. 10a,b) and mantle the prior units (Fig. 10c). The outcrop appearance is characterized by surfaces polished by glacial abrasion (Fig. 10d) and in some cases, the lavas preserve basal breccias and primary morphologies (Fig. 10e).

\subsection{Unit G}

This unit is restricted to the upper parts of the edifice $(>2450 \mathrm{~m}$ a.s. 1.), except on the northern flank where it reaches $2150 \mathrm{~m}$ a.s.l extending $3 \mathrm{~km}$ downhill. Similar to Unit D, this unit comprises a minor volcaniclastic basal section covered by an upper section composed of lava (Fig. 11a).

The basal section is composed of downslope-dipping bedded lapilli tuff (bLT) up to $4 \mathrm{~m}$ thick, preserved toward east and south of the active crater (Fig. 11b). Bedding is planar and subparallel to the previous topographic surface. The beds vary in thickness from centimeter to $>1 \mathrm{~m}$ and are defined by grain-size variation (Fig. 11c). The thin ones range from well-sorted clast-supported lapilli-size beds to matrix-supported composed of lapilli-size clasts in a light grey ash-size matrix. Some clastsupported beds include block-size fragments even up to $30 \mathrm{~cm}$ but they do not show associated impact sags structures. The metric-scale beds are massive and matrix-supported. The clasts of angular dark grey lava fragments dominate in the whole size range. 

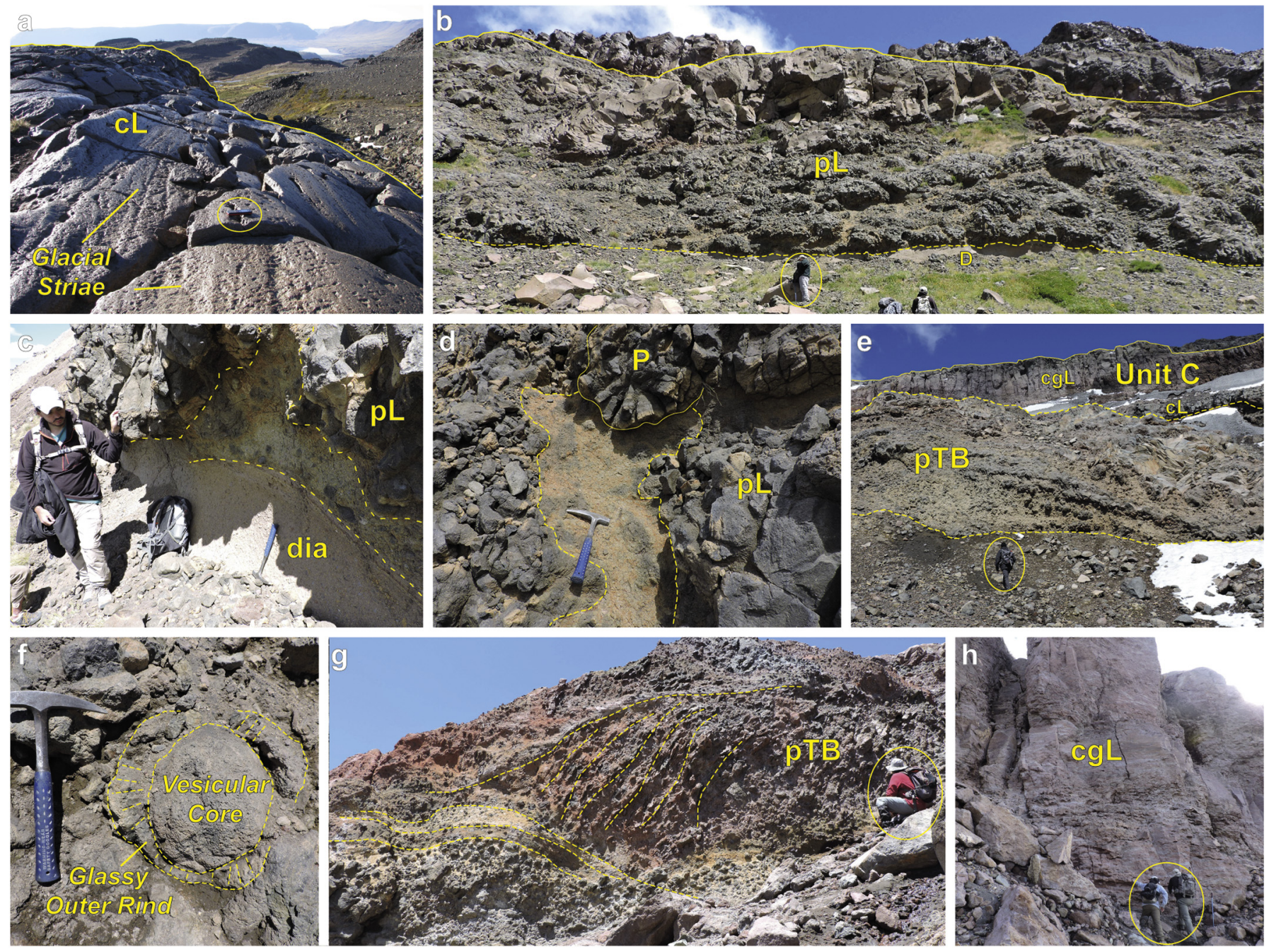

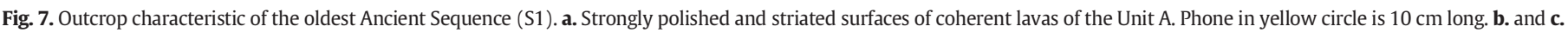

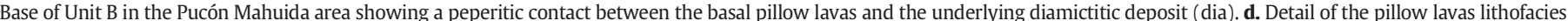

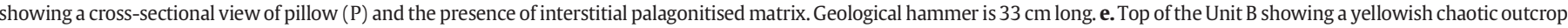

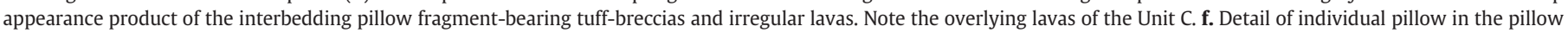

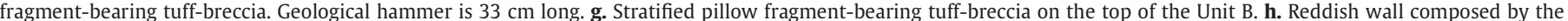
clastogenic lavas of the Unit C. (For interpretation of the references to colour in this figure legend, the reader is referred to the web version of this article.)

The upper section is formed by lavas that show an erosive contact with the underlying bedded lapilli tuff represented sometimes by a basal breccia. Where the basal volcaniclastic section is missing these lavas cover previous units (usually Unit B, C, and F). The lavas are highly fractured by cooling joints (fL) and exhibit over-thickening by confinement. The fractures range from fine-scale columnar joints (Fig. 11d), pseudo-pillow fractures, and hackly fractures in the margins, to curved and concentric platy joints in internal sectors (Fig. 11e).

\subsection{Unit $H$}

Unit $\mathrm{H}$ group lavas do not display evidence of glacial erosion. These lavas were fully described in previous work and grouped in a "post-glacial stage" (Melnick et al., 2006). In the mapped area, Unit H is mainly represented by a lava flow emitted from a fissure in the northeast flank. This lava flow extends for approximately $5 \mathrm{~km}$ covering Unit A and glacial deposits. In addition, a $700 \mathrm{~m}$-long minor lava flow overlying the body formed by units $\mathrm{D}$ and $\mathrm{F}$ is also included in this unit. Both lava flows have typical 'A'à surfaces, and basal and frontal auto-breccias (Fig. 12a).

\subsection{Unit I}

Unit I consists of all the volcaniclastic deposits produced by the historic activity of the Copahue volcano. These deposits are located in a $1.5 \mathrm{~km}$ radius around the current active crater and in the stream valleys located on the volcano flanks. Of particular note, the volcaniclastic deposits outcropping in the Lomín and upper Agrio rivers reach a maximum distance of $4 \mathrm{~km}$ and $6 \mathrm{~km}$ respectively, from the active crater. In the mapped area, three main deposits can be recognized (Fig. 12b). The lower deposit is preserved just east of the active crater and consists of a laminated lapilli tuff (ILT) up to $\sim 3 \mathrm{~m}$ thick. The stratification is parallel planar with $1-5 \mathrm{~cm}$ thick beds. Fragments are mainly lapilli-size $(<5 \mathrm{~cm})$ dark grey to brown vesicular scoria with minor, generally smaller, volcanic lithics supported in an ash-size matrix. This lower deposit is interpreted as a product of a pyroclastic surge emplaced during an unidentified historic eruption. The intermediate deposit is composed of light grey to whitish massive lapilli tuff ( $\mathrm{mLT}$ ) that reaches up to $55 \mathrm{~cm}$ thick and shows non-erosive contacts with the previous deposit. This deposit is clast-supported and polymict, formed by poorly sorted fine ash to fine lapilli-sized fragments predominantly lithics. The lithics 

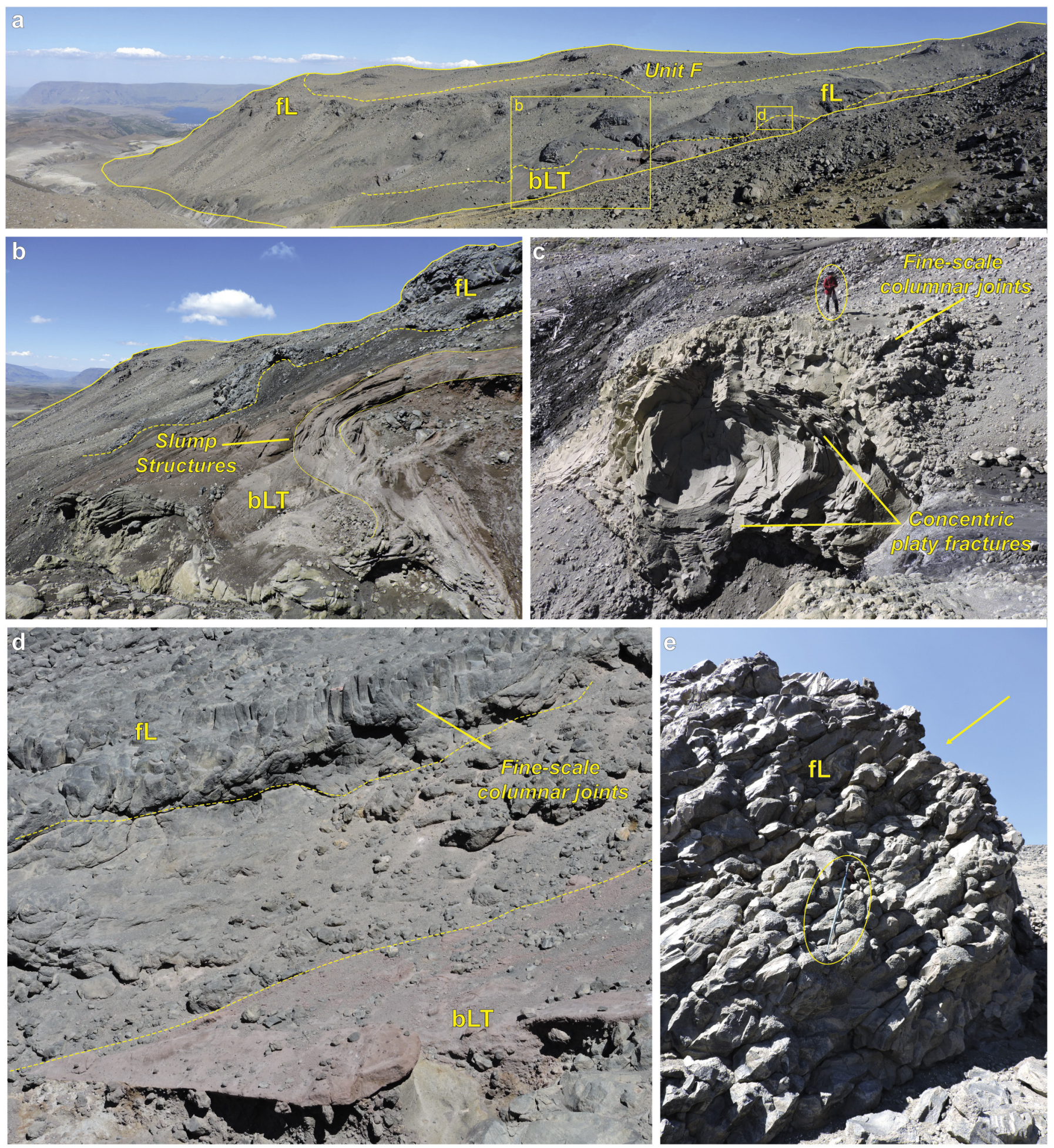

Fig. 8. Outcrop characteristic of the Unit D. a. Overview of the thick body of Unit D in the upper Agrio River showing a basal bedded lapilli tuff and marginal fractured lavas cover by coherent lavas of Unit F. Note the flat top and steep fronts cover by debris fans. The yellow square marks the position of the figure $b$ and d. $\mathbf{b}$. Outcrop in the upper Agrio River showing distinctive large-scale slumps in the basal bedded lapilli tuff. c. Fractured lavas in the margin body showing concentric platy joints and fine-scale columnar joints. d. Detail of the contact between the volcaniclastic basal section and the fractured lavas of the margin of the body showing fine-scale columnar joints. Field of view is $\sim 5 \mathrm{~m}$. e. Highly fractured lavas showing oblique fractures orientations (yellow arrow). Trekking pole in yellow circle is $120 \mathrm{~cm}$ long. (For interpretation of the references to colour in this figure legend, the reader is referred to the web version of this article.)

are mainly composed of white sub-rounded fragments of amorphous silica and grey-greenish spherical fragments of sulfur. Juvenile fragments are scarce and exhibit blocky or vesicular textures. This volcaniclastic deposit was previously interpreted either as the product of a lahar generated during 1992-1995 eruptive cycle (Delpino and Bermúdez, 1993) or as a pyroclastic density current deposit emplaced during the 2000 eruption (Balbis et al., 2016). The upper deposit includes unconsolidated lapilli (uLP) and isolated volcanic bombs and blocks $(\mathrm{uB})$. These pyroclasts were ejected during the last eruptive cycle (2012-2019) mainly in the major December 

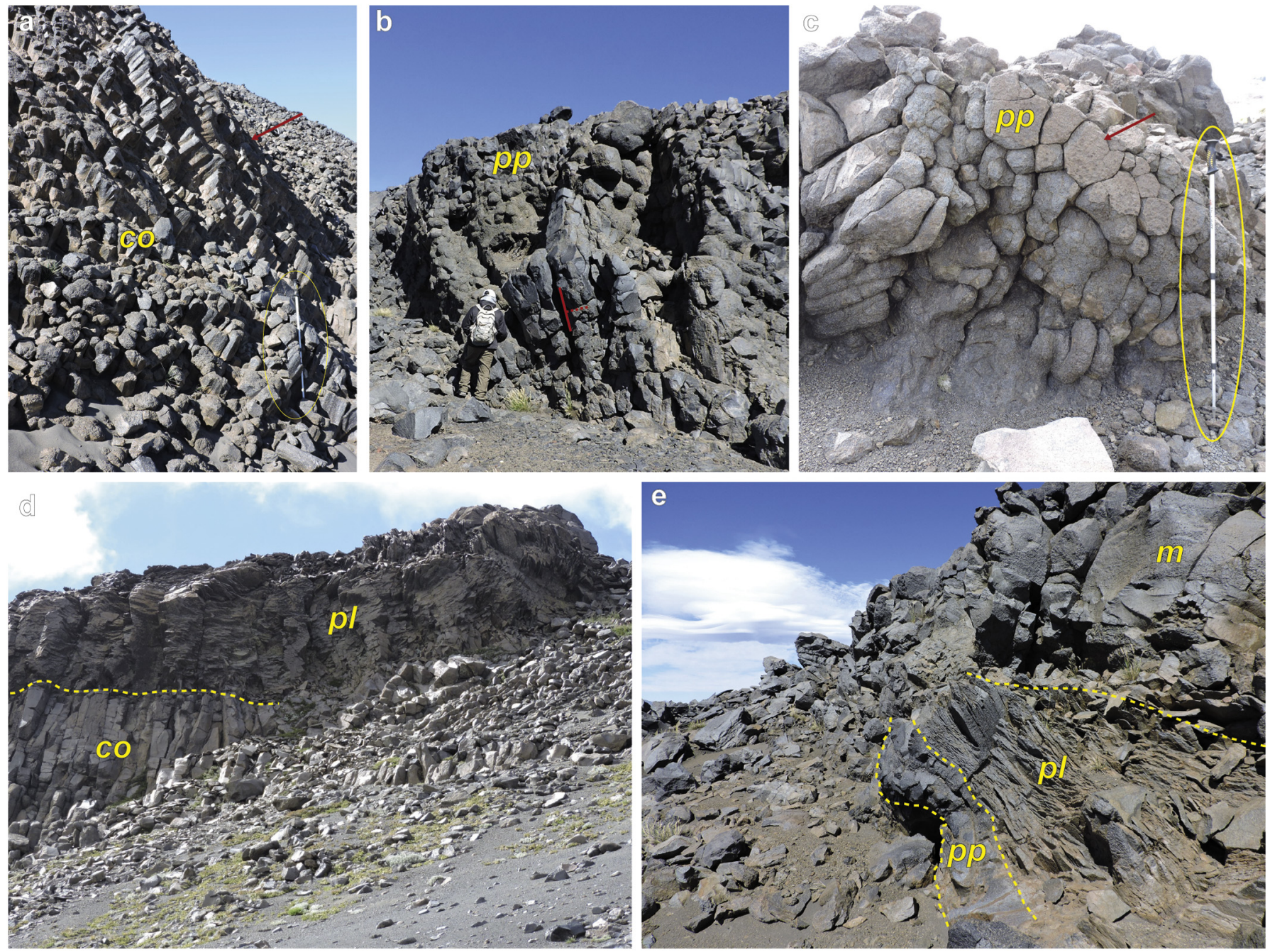

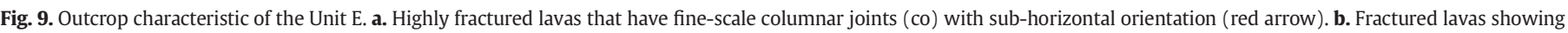

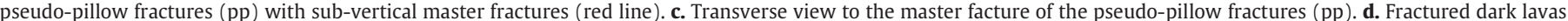

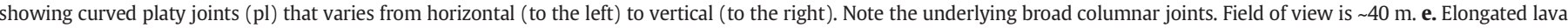

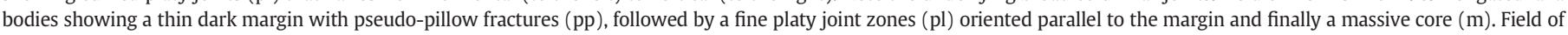
view is $\sim 6 \mathrm{~m}$. (For interpretation of the references to colour in this figure legend, the reader is referred to the web version of this article.)

$22^{\text {nd }}, 2012$ eruption (Petrinovic et al., 2014; Caselli et al., 2016b). The deposit varies in thickness and is preserved up to $1.5 \mathrm{~km}$ from the active crater, especially toward the east flank. The lapilli-sized components correspond to dark grey to brown vesicular scoria. A minor amount of ash size components is also present. The volcanic bombs are black in colour, moderately to highly vesiculated and reach up to $\sim 2 \mathrm{~m}$. The volcanic blocks reach $50 \mathrm{~cm}$ and correspond to greyish highly altered fragments impregnated with sulfur.

Currently the active crater hosts a crater lake fed by meltwater from the glacier located in its western wall, and a pyroclastic cone formed during the post-2015 activity (Fig. 12c).

\section{Discussion}

\subsection{Evidence of glaciovolcanism}

The diagnostic criteria of a glaciovolcanic origin are features indicating: (1) presence of abundant water in terrestrial environments where lakes are unlikely and (2) confinement in areas where physical barriers are not evident (e.g. Lescinsky and Fink, 2000; Edwards et al., 2015; Cole et al., 2018). In the following sections, we discuss the evidence of different kinds of lava-ice interactions in the Copahue volcano.

\subsubsection{Eruptions beneath an englacial lake}

The first unit in the evolution of the volcano that presents evidence of glaciovolcanism is Unit B (Fig. 13a). This unit contains basal pillow lavas $(\mathrm{pL})$, which are a diagnostic lithofacies of underwater eruptions (Walker, 1992; White et al., 2015), but not necessarily in a glacial setting. However, the location of the deposit ( $\sim 2200 \mathrm{~m}$ a.s.l and steep topography) leads us to infer that the most feasible mechanism to accumulate this water is the retention of meltwater generated during an eruption beneath a thick impermeable ice cap (Stevenson et al., 2009; Russell et al., 2014; Smellie and Edwards, 2016). Edwards et al. (2015) indicate that the englacial lakes at the base of a thick ice cap are rapidly generated since the volume of melted ice is greater than the erupted material. There are several cases of pillow lavas formed in early stages of subglacial eruptions in thick ice (e.g. Skilling, 1994; Edwards et al., 2009; Pollock et al., 2014; Russell et al., 2014; Graettinger et al., 2019). The peperitic contact with the underlying glacial deposits also supports the inference that pillow lavas are coeval with ice (Smellie and Edwards, 2016). 

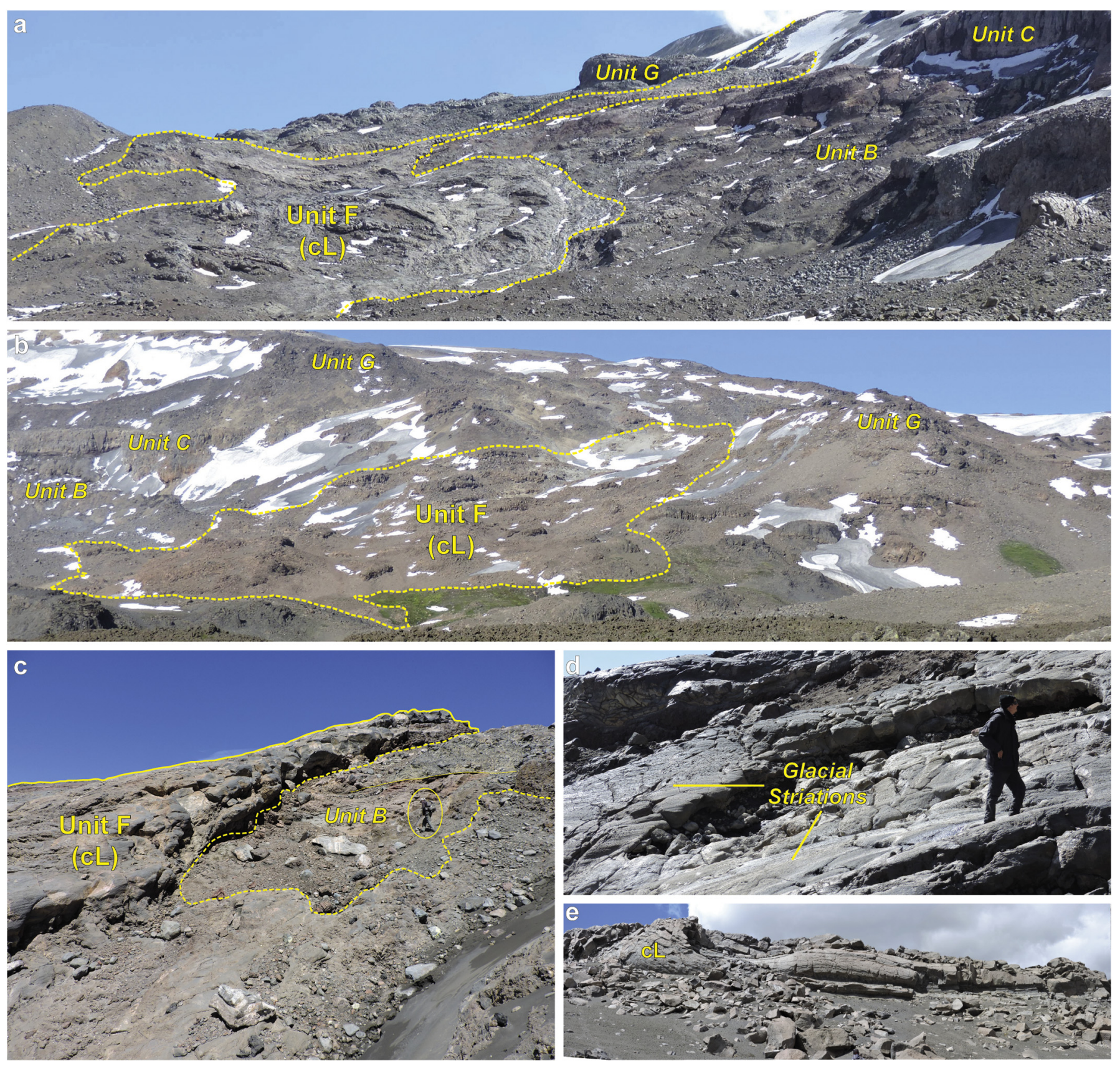

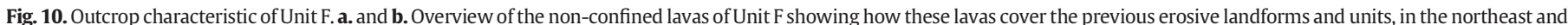

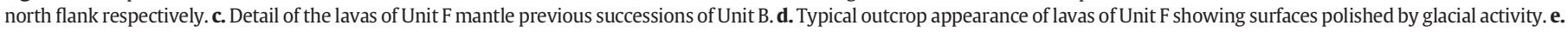
Lava tube preserved in coherent lavas. Field of view is $\sim 50 \mathrm{~m}$.

The overlying thick succession of pillow fragment-bearing tuffbreccias (pTB) is interpreted as the continuation of the volcanic activity in the same environment. Pillow lava fragments and pervasive palagonitization indicate the presence of water, supporting this interpretation. Part of this succession could be a consequence of gravitational collapse of the growing pillow lava accumulation (e.g. Pollock et al., 2014; Edwards et al., 2009). However, the bedding in the top of the succession and the presence of interbedded lava lobes indicate that it was formed in a foreset position of a lava-fed delta. Lava-fed deltas comprises dipping successions of breccias and lava lobes that form when the growing edifice exceeds the surface of the englacial lake producing the emission of subaerial lavas that flow from the vent to the shoreline and ultimate enter the lake (e.g. Skilling, 2002; Skilling, 2009; Edwards et al., 2011; Russell et al., 2014; Edwards et al., 2015; Smellie and Edwards, 2016).
On the northeast flank, Unit B is covered by the subhorizontal lavas ( $\mathrm{cL}$; $\mathrm{cgL}$ ) of Unit $\mathrm{C}$. The latter could be interpreted as the subaerial lava cap of the lava-fed delta. The limit between units $B$ and $C$ represents the subaqueous-subaerial limit (passage zone), which indicates the fossil water level and can be used as a paleoclimate proxy (e.g. Jones, 1969; Skilling, 2002; Russell et al., 2014; Edwards et al., 2015).

\subsubsection{Ice-confined lavas}

The lavas ( $\mathrm{fL}$ ) of units D and $\mathrm{G}$ are classified here as ice-confined lava flows since they show cooling fracture varieties largely interpreted as a result of quenching caused by contact with ice/water (Lescinsky and Fink, 2000; Spörli and Rowland, 2006; Lodge and Lescinsky, 2009; Forbes et al., 2012; Forbes et al., 2014b).

In the case of Unit D, these glaciovolcanic features were previously observed by Melnick et al. (2006), who proposed a subglacial 

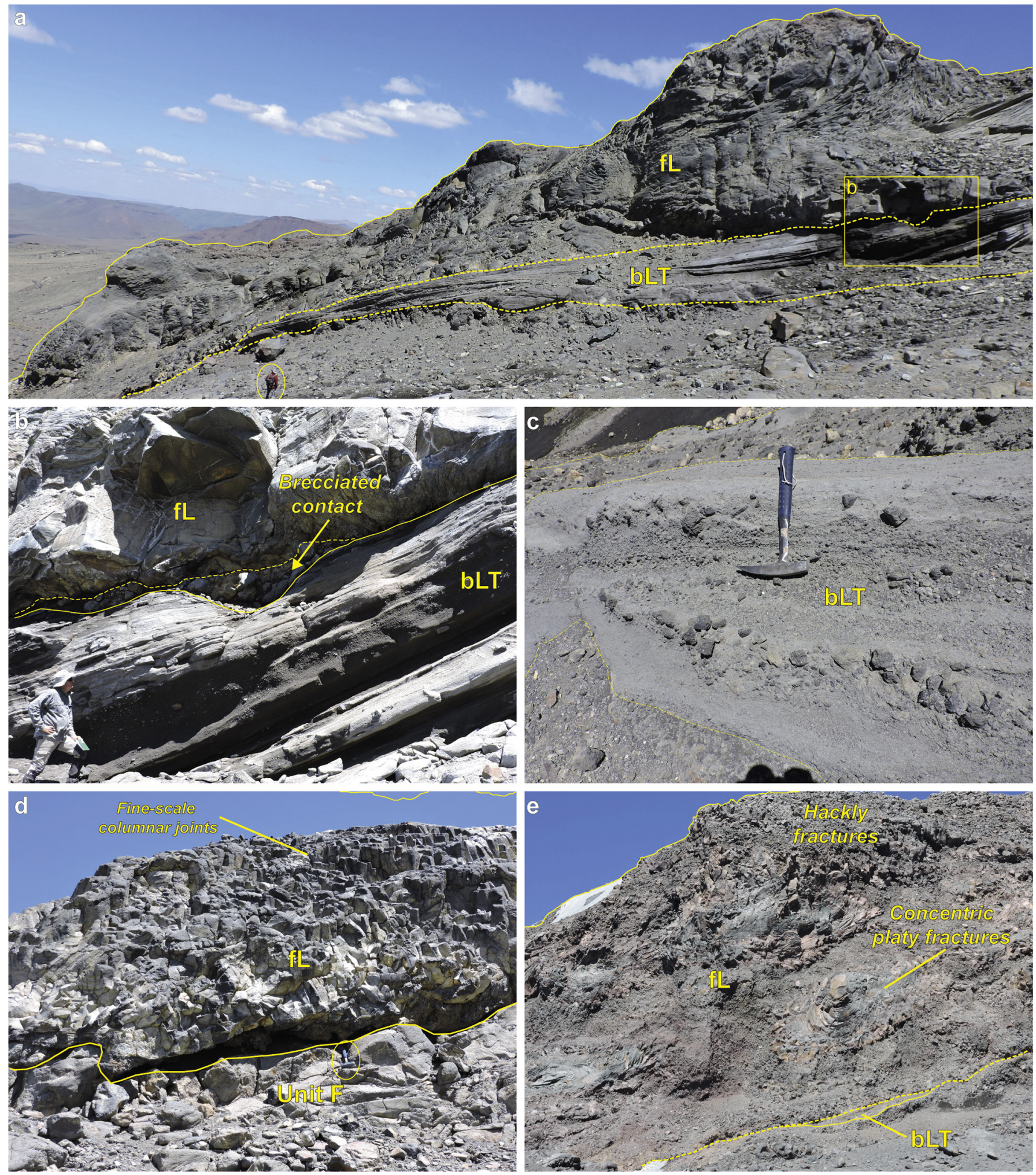

Fig. 11. Outcrop characteristic of Unit G. a. Overview of Unit $\mathrm{G}$ on the east flank showing the volcaniclastic basal section covered by the upper section composed of over-thickened fractured lavas. The yellow square mark the location of the figure b. b. Lapilli tuff in the east flank showing bedding planar and subparallel to the previous topographic surface. Note the brecciated limit generated by the emplacement of the overlying lava. c. Detail of the grain-size variation in the lapilli tuff showing beds that range from clast-supported lapilli-size beds to matrixsupported composed by lapilli-size clast in an ash-size matrix. d. Lava of the upper section showing fine-scale columnar joints. Note the lack of the volcaniclastic basal section in this point. Geological hammer in yellow circle is $27 \mathrm{~cm}$ long. e. Over-thickening lava located south of the active crater showing hackly fractures and concentric platy joints. Note the volcaniclastic basal section below the thick lava succession. Field of view is $\sim 200 \mathrm{~m}$. (For interpretation of the references to colour in this figure legend, the reader is referred to the web version of this article. 

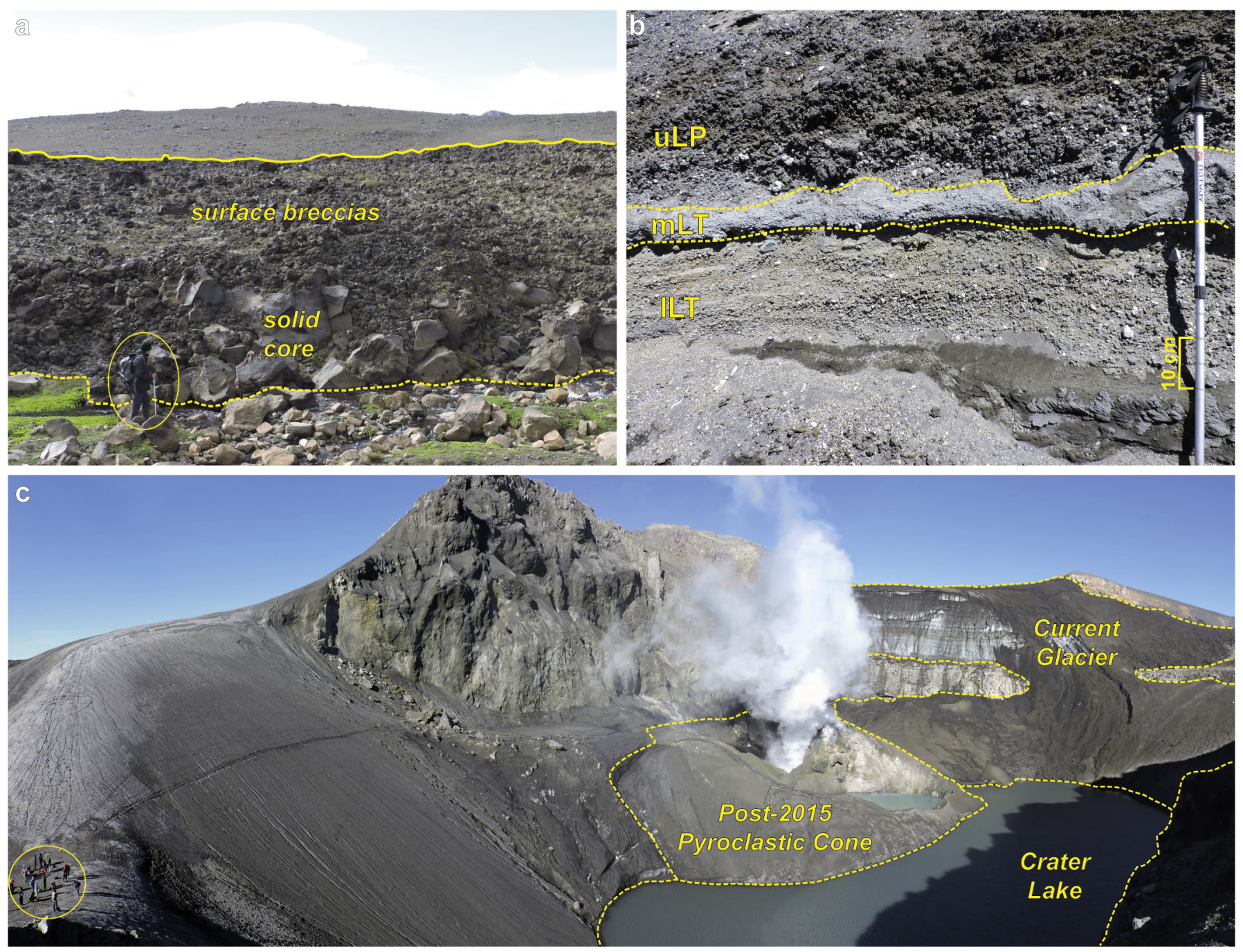

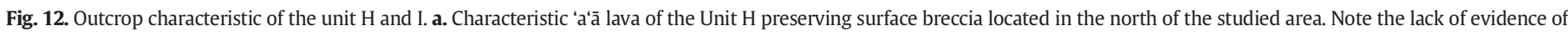

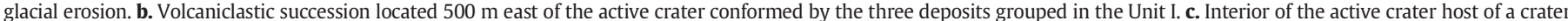

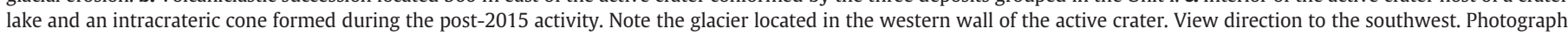
taken in March 2018.

setting. Melnick et al. (2006) also mention the presence of isolated pillow lavas in the top of the body. However, our field observations suggest that the lavas of the top were cooled subaerially and they were included in Unit F. The occurence of cooling fractures in marginal zones of the main body and their variable orientation (usually perpendicular to the vertical margin) indicate that the lava flows were subaerially emitted and downstream interacted with ice generating a vertical cooling surface (e.g. Lescinsky and Sisson, 1998; Lescinsky and Fink, 2000). The thicknesses and aspect ratio of the main body show that the ice also worked as a barrier that partially restricted the movement of the lava flows, therefore the latter are classified here as ice-dammed lava flows (Mathews, 1952; Edwards and Russell, 2002; Mee et al., 2006; Conway et al., 2015; Cole et al., 2018).

The lavas ( $\mathrm{fL}$ ) of Unit $\mathrm{G}$ also exhibit features that allow us to classify them as lavas constrained by an ice barrier. These lavas are restricted to the upper parts of the edifice showing over-thickening and forming thick ridges in the flanks of the edifice indicating that their movement was laterally restricted by unpreserved barriers, in this case interpreted as ice barriers. These features in conjunction with the presence of the cooling fractures in the lateral margin of the lavas lead us to classify them as ice-bounded lavas (Lescinsky and Sisson, 1998; Conway et al., 2015).

\subsubsection{Syn-eruptive meltwater drainage streams}

The outcrops of volcaniclastic deposits corresponding to Unit D located in the upper Agrio River were previously interpreted as pyroclastic surge deposits belonging to a "pre-glacial stage" (Sruoga and Consoli, 2011a; Caselli et al., 2016a), while those corresponding to Unit G were not identified previously.

Several examples of bedded volcaniclastic deposits have been recognized in glaciovolcanic sequences interpreted as syn-eruptive deposits forming by meltwater drainage streams (e.g. Loughlin, 2002; Tuffen et al., 2002; Harder and Russell, 2007; Skilling, 2009; Cole et al., 2018; Lachowycz et al., 2015). A syn-genetic relationship with the overlying ice-confined lavas is proposed for bLT based on the dominant composition of fragments of similar lavas added to the close spatial association and contact between both units. Thus, the volcaniclastic deposits formed by bedded lapilli tuff (bLT) located underlying the iceconfined lavas of units D and G were likely emplaced by meltwater drainage streams.

The bLT lithofacies contains evidence of soft-sediment deformation that indicates deposition in a water-saturated setting. Although softsediment deformation is common in wet pyroclastic surge deposits (Moorhouse and White, 2016), the lack of any distinctive features of this type in bLT, such as impact sag structures associated with blocksize fragments, accretionary lapilli, armoured lapilli or fine ash- 


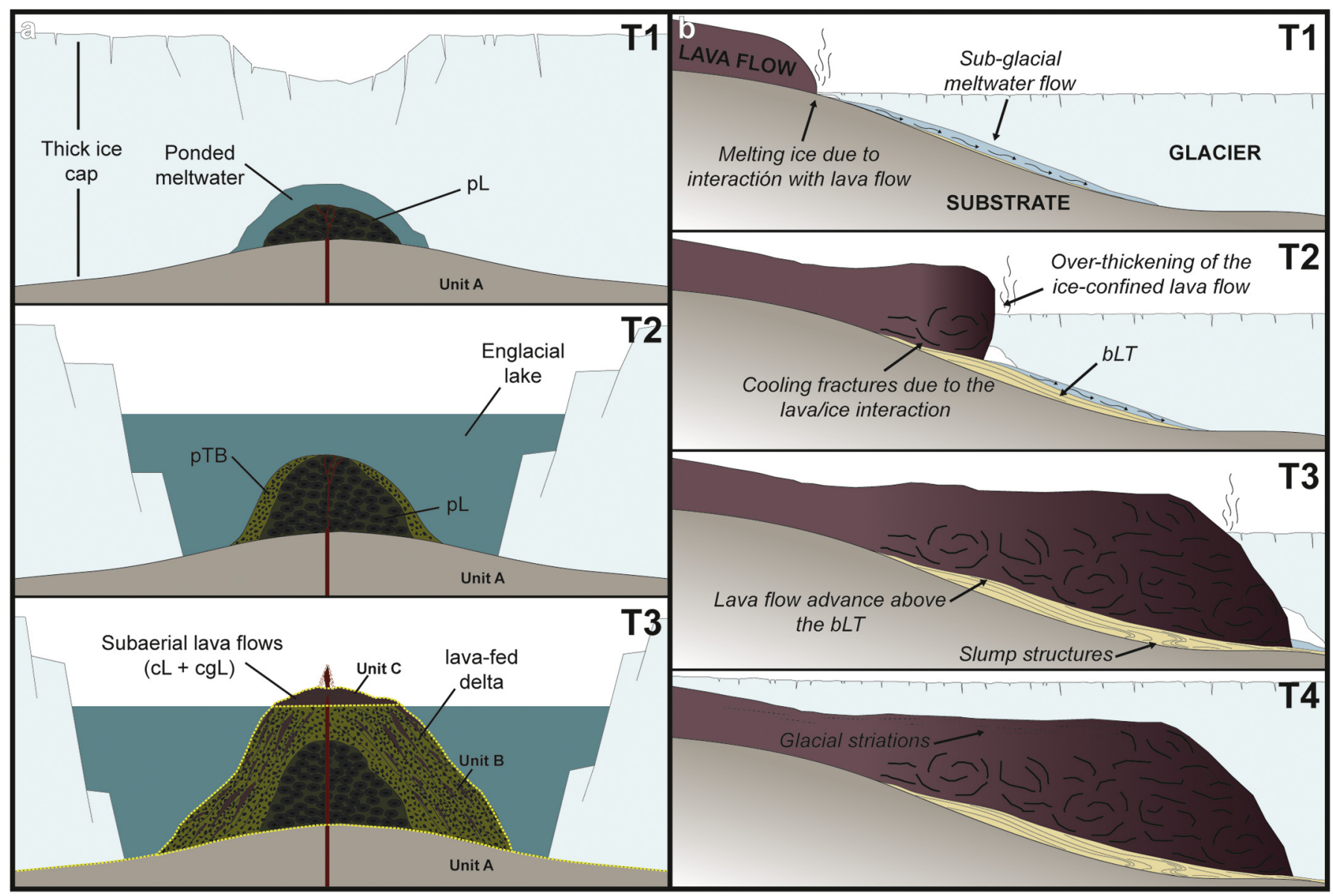

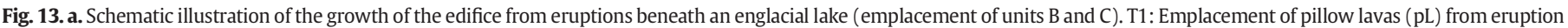

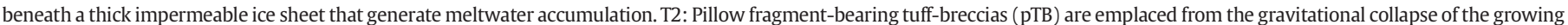

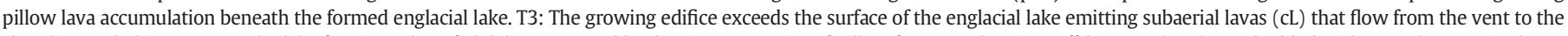

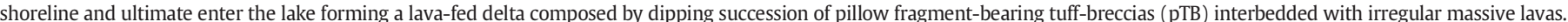

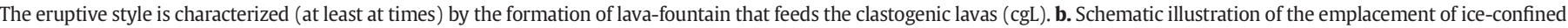

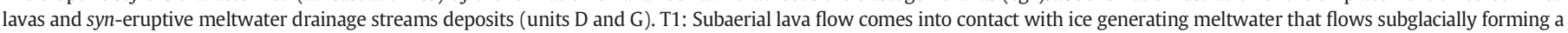

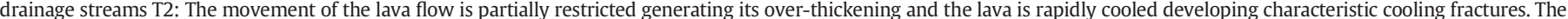

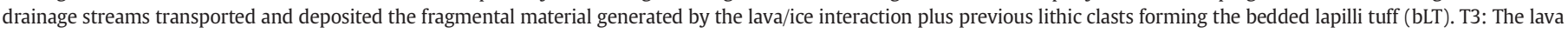

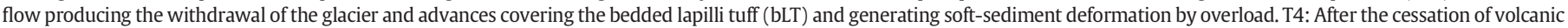
activity the glacier recover their original extension.

draping beds (Cas and Wright, 1987; Moorhouse and White, 2016; Cole et al., 2018), makes this origin unlikely.

The general features of the bedded lapilli tuff lithofacies in conjunction with evidence of interaction with ice of the spatially related lavas (see above) connotes that emplacement of the D and $G$ units (Fig. 13b) proceeded as follows. When the subaerial lava interacted with the glacier a significant amount of meltwater was generated and drained subglacially. The streams transported and deposited the fragmental material generated by the lava/ice interaction plus previous lithic clasts. The bedded characteristics support a progressive deposition with fluctuating aggradation rates (McPhie et al., 1993; Harder and Russell, 2007). Despite being partially confined by the ice, lava advances caused the withdrawal of the glacier, covering the volcaniclastic deposit and producing the soft-sediment deformation by overloading. After the cessation of volcanic activity the glaciers recovered their original extent.

\subsubsection{Subglacial lavas}

Some of the lavas of Unit E were previously included in a "syn-glacial stage" by Melnick et al. (2006). These authors proposed a subglacial origin for these lavas. We agree with this interpretation extending it to all the lava bodies that form Unit E. The carapace of glassy dark texture and the cooling fractures with fan arrays in their orientation support the subglacial emplacement setting (Mathews, 1958; Hickson, 2000; Lescinsky and Fink, 2000).

In this context, the distinctive elongated morphologies that are exhibited by some lavas of Unit E indicatethat these probably were emplaced in tunnels carved in the ice, analogous to esker-like lava flows (e.g. Hickson, 2000; Lescinsky and Fink, 2000; Kelman et al., 2002; Smellie, 2013; Conway et al., 2015; Smellie and Edwards, 2016). This type of landform is usually interpreted as lava flows disconnected from the vent rather than flank eruptions (Smellie, 2013; Smellie and Edwards, 2016). The lack of pillow lavas and pillow fragment-bearing breccias related to the lava bodies of Unit E suggest an ineffective accumulation of meltwater due to the drainage through subglacial tunnels and a subsequent decrease in watermagma interaction (Smellie and Skilling, 1994; Lescinsky and Fink, 2000; Loughlin, 2002; Stevenson et al., 2009; Lachowycz et al., 2015; Smellie and Edwards, 2016).

In the case of the lava bodies with low aspect ratios, an origin related to subglacial flank eruption, similar to subglacial domes, cannot be ruled out (Lescinsky and Fink, 2000; Kelman et al., 2002; Smellie and Edwards, 2016). 


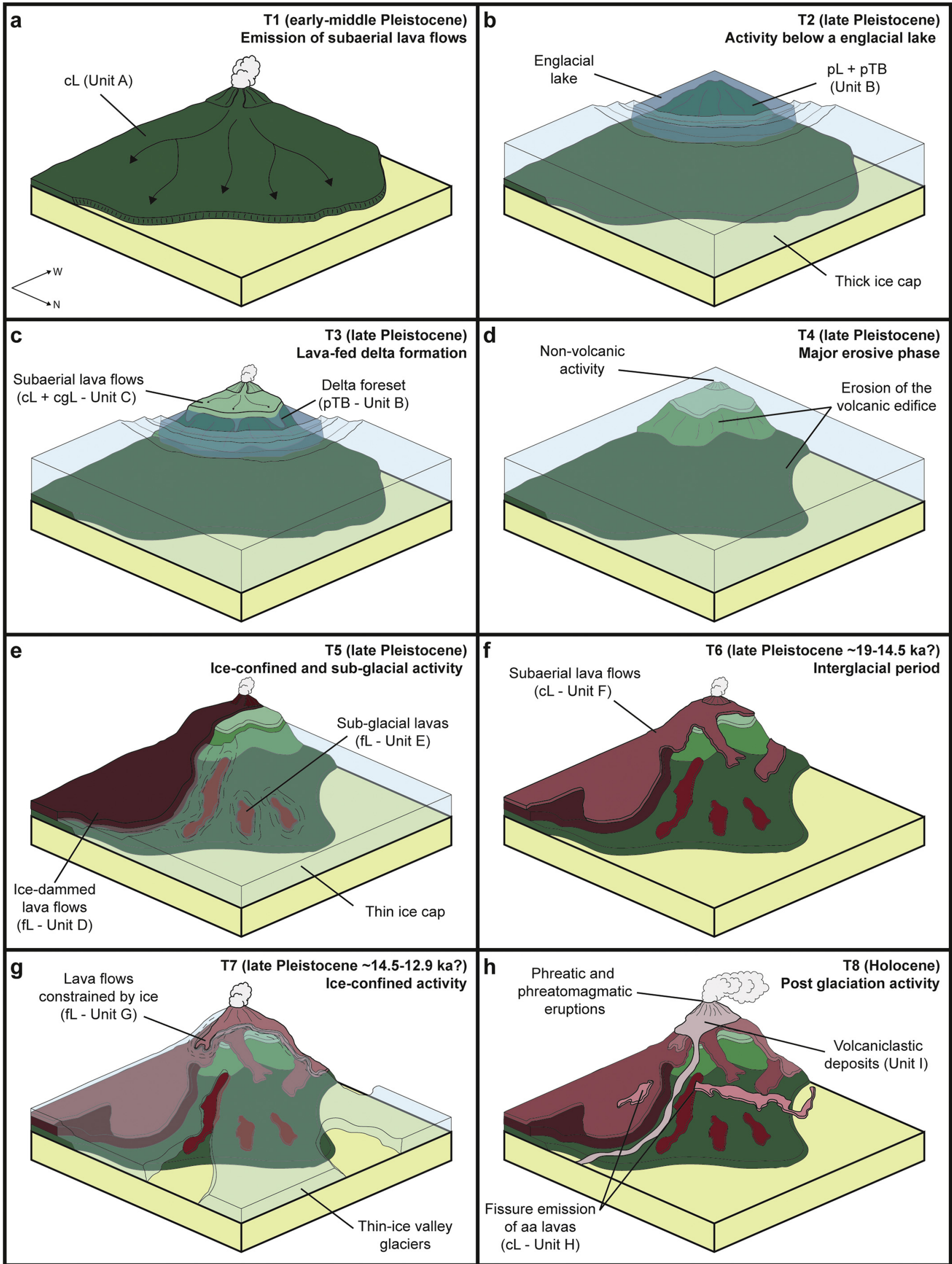




\subsection{Paleoclimatic implications}

The englacial lake in which Unit B was emplaced required ponding of meltwater, thus the thickness of the overlying ice must have been enough to become impermeable and form a hydraulic seal that inhibits drainage (Stevenson et al., 2009). "Thick ice" is usually defined as $>150$ m thick (Smellie and Skilling, 1994; Smellie, 2001), although Stevenson et al. (2009) suggest that thicknesses $>300 \mathrm{~m}$ are necessary to efficiently accumulate meltwater, especially in steep topography. Absolute values of ice thickness (although relativity inaccurate) can be estimated by measuring the volatile content $\left(\mathrm{H}_{2} \mathrm{O}\right.$ and $\left.\mathrm{CO}_{2}\right)$ in volcanic glass erupted subglacially to obtain eruption pressures (Dixon et al., 2002; Schopka et al., 2006; Edwards et al., 2009; Tuffen et al., 2010; Owen et al., 2012) or from the elevation of the subaqueous-subaerial limit or passage zone (Smellie, 2000, 2008; Smellie et al., 2011; Russell et al., 2013; Edwards et al., 2009). In the second case the value obtained represents only the level of the englacial lake coeval with the eruption providing a minimum ice sheet thickness (Smellie, 2000; Russell et al., 2013).

On the eastern flank of Copahue volcano the limit between units B and $C$ that represents the subaqueous-subaerial limit is located at $\sim 2520 \mathrm{~m}$ a.s.l. If we consider a pre-eruptive topography without major variations, a rough ice thickness estimation can be made using the position of the base of unit B in the Pucón Mahuida area ( $2180 \mathrm{~m}$ asl), resulting in a minimum ice cap thickness of $\sim 340 \mathrm{~m}$. This value is consistent with the thicknesses estimated by González Díaz (2003, 2005), who proposed an ice cap up to $500-800 \mathrm{~m}$ in the interior of the Caviahue caldera. According to this author, the ice cap had outlet glaciers that exceeded the rim of the caldera and flowed down to the north, east and south (the west rim is occupied by the Copahue volcano). The caldera rim reaches up to $2250 \mathrm{~m}$ a.s.l., which could be considered a minimum ice cap elevation level, slightly lower than that estimated from the passage zone.

The same glacial period continued affecting the area until the emplacement of the units D and E. However, a period of non-volcanic activity must have occurred to enable the significant erosion that affects units B and C. Although erosion can occur simultaneously to the edifice growth, the more aggressive erosion occurred during non-eruptive phases (e.g. Karátson et al., 2012).

The evidence of efficient drainage that inhibited ponding of the meltwater in units D and $\mathrm{E}$ indicates that the thickness of the ice during their emplacement was lower than in the case of Unit B (Smellie and Skilling, 1994; Lescinsky and Fink, 2000; Loughlin, 2002; Stevenson et al., 2006; Smellie et al., 2011). Therefore, we propose a stage of glacial recession for the time of the emplacement of units $\mathrm{D}$ and $\mathrm{E}$.

The glaciovolcanic features of Unit $G$ record a younger glacial period separated from the previous one by an interglacial period in which the subaerial lavas of Unit F were emitted. The basal volcaniclastic deposit related with the drainage of the meltwater produced by the lava/ice interaction indicates a glacial setting with relatively thin permeable ice $<150$ m thick (Smellie and Skilling, 1994; Lescinsky and Fink, 2000; Loughlin, 2002; Stevenson et al., 2006; Smellie et al., 2011). The apparent lateral confinement and restricted position in the upper parts of the edifice forming ridges of lava flows in Unit $\mathrm{G}$, along with the evidence of lava-ice interaction, supports this interpretation and indicates that the lava flows were restricted by the presence of glaciers (Lescinsky and
Sisson, 1998; Conway et al., 2015). Thus, the second glacial period related to Unit $G$ would have been less significant than the previous one, probably characterized by the development of the valley glaciers fed from the top of the edifice in contrast to the oldest thick ice cap.

The interpretations discussed above support the original interpretation of the development of two glaciations in the Copahue-Caviahue area during the late Pleistocene (Groeber, 1925), in contrast to the most recent proposal of a single glaciation (González Díaz, 2003). We suggest that the oldest and more significant glaciation during which units B, C, D, and E were emplaced, corresponds to the single glaciation proposed by González Díaz (2003) and with the first glaciation proposed by Groeber (1925). Bermúdez and Delpino (1999) measured an age of $30 \mathrm{ka}$ on a fluvioglacial deposit likely associated with the first main glacial period. Zech et al. (2017) found evidence of glacial activity at $\sim 45-40$ and $\sim 21-18 \mathrm{ka}$ in the Rucachoroi valley, $150 \mathrm{~km}$ southward from the Copahue volcano. Therefore, this first glacial expansion appears to have been generated between the end of the Marine Isotope Stage 3 (MIS 3, between 57 and 29 ka; Darvill et al., 2015; Hein et al., 2017) and the Last Glacial Maximum period (LGM, between 26.5 and 19.0 ka; Clark et al., 2009).

The younger glacial period recorded by Unit G corresponds to the second glaciation of the original proposal of Groeber (1925). Based on the glacial activity recorded in Patagonia during the late Pleistocene, this less extensive glacial period can be associated with the late glacial advances during the Antarctic Cold Reversal (ACR) occurred during 14.5-12.9 ka (Strelin et al., 2011; García et al., 2012; Sagredo et al., 2018; Zech et al., 2017).

The available geochronological data of the Copahue volcano (Linares et al., 1999) indicate older ages than those interpreted in the present work from the glaciovolcanic evidence. However, the new age obtained for the oldest Las Mellizas volcanic sequence (125 ka; Sruoga and Consoli, 2011b) implies that de Copahue volcano is younger than Middle Pleistocene and highlights the need for new geochronology covering the entire edifice.

\subsection{Glaciovolcanic evolution of the Copahue volcano}

Evolution of the Copahue volcano is closely linked to glacial and inter-glacial periods developed during the last glaciation of the late Pleistocene (Fig. 14). The initial stage of the S1 was dominated by effusion of subaerial lava flows during the early-middle Pleistocene (Unit A, Fig. 14a). During the late Pleistocene an important glacial period began that determined the environmental setting in which units B, C, D and E were emplaced. The first glaciovolcanic activity recorded in the stratigraphy of Copahue Volcano occurs below a thick ice cap generating an englacial lake under which the volcanic edifice started to grow (Unit B, Fig. 14b). As the edifice emerged from the englacial lake, the eruptions changed to subaerial effusive emissions of lava flows (Unit C) that reached the shoreline of the lake forming a lava-fed delta (Fig. 14c). After this eruptive stage, a non-eruptive period started in which glacial erosion became more effective and heralded a major erosive phase (Fig. 14d). This period should have been relatively short but with high rates of erosion, since the initial stage of the began while the ice cap was still significant, but probably retreating. In this setting, lava flows emitted in a subaerial central position of the edifice interacted downstream with the ice, being partially dammed (Unit D, Fig. 14e).

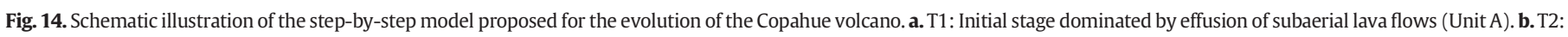

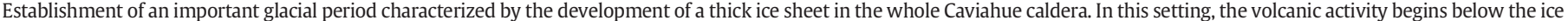

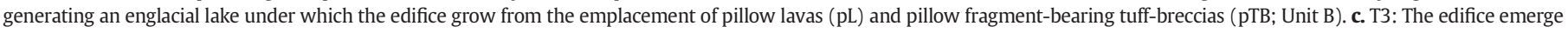

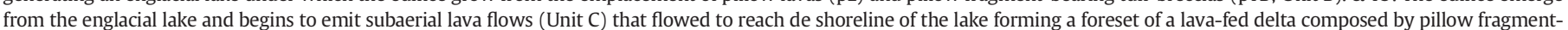

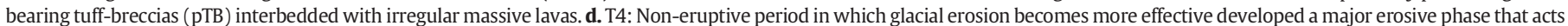

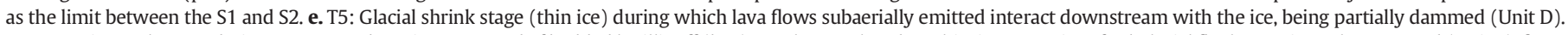

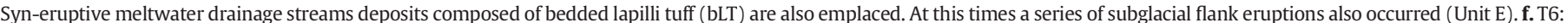

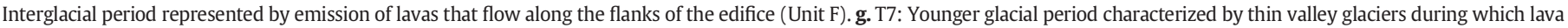

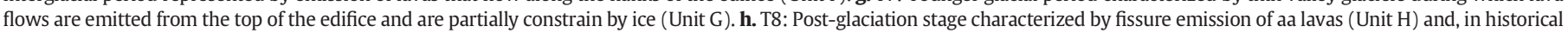
times, by phreatic-phreatomagmatic eruptions recorded by the volcaniclastic deposits grouped in Unit I. 
At this time a series of subglacial flank eruptions also occurred (Unit E). Later, a warmer interglacial period was established during which the volcanic activity was represented by effusive eruptions that emitted lava flows down along the flanks of the edifice without either confinement and/or interaction with ice (Unit F, Fig. 14f). The previous warmer setting was replaced by a younger glacial period (ACR; 14.5-12.9 ka?) characterized by valley glaciers. These partially constrained the movement of the coeval lava flows resulting in their over-thickening and restricting them to the upper parts of the edifice (Unit G, Fig. 14g). With the end of this younger glacial period, a post-glaciation stage characterized by fissure emission of aa lavas (Unit $\mathrm{H}$ ) initiated. Finally, in historical times, dominantly phreatic-phreatomagmatic activity occurred within the currently active crater, recorded by Unit I (Fig. 14h).

\section{Concluding summary}

The principal achievements of this contribution are summarized as follows:

The evolution of the Copahue volcano is closely linked to glacial and inter-glacial periods developed during the last upper Pleistocene glaciation. Two main sequences can be identified: the Ancient Sequence (S1) and the Young Sequence (S2), that are separated by a major erosive phase. The sequence $S 1$ is represented by an initial subaerial effusive stage followed by a major glaciovolcanic stage associated with a thick ice cap and characterized by the growth of the edifice beneath an englacial lake and the subsequent formation of a lava-fed delta. The sequence S2 is represented by mainly effusive activity during periods of glacial advances and retreat characterized by an alternation of unconfined subaerial lavas and ice-confined lavas.

The new stratigraphic scheme proposed here is based on the recognition of major constructive and destructive phases in the evolution of the Copahue volcano rather than its temporal relationship with glaciations. We have found glaciovolcanic and glacial features throughout most of the Copahue volcano stratigraphy that renders the use of a stratigraphic criteria like pre- syn- and post- glacial sequences ineffective to fully represent the eruptive history of the volcano.

Two glaciations are recognized in the Copahue-Caviahue area during the late Pleistocene. During the oldest glaciation a thick ice cap $(>300 \mathrm{~m})$ is proposed at least during the emplacement of units B and C. The same glacial period continued until the emplacement of units D and $\mathrm{E}$ but with glacial shrinkage and lower ice thicknesses $(<150 \mathrm{~m})$. The second glacial period, registered by Unit G, was less significant and was characterized by relatively thin $(<150 \mathrm{~m})$ glaciers, probably valley glaciers. Based on the glacial history in the surrounding area we tentatively correlate the first glaciation with the end of the Marine Isotope Stage 3 (MIS 3, between 57 and $29 \mathrm{ka}$ ) and/or the Last Glacial Maximum period (LGM, between 26.5 and $19.0 \mathrm{ka}$ ), and the second lessextensive glacial period with the Antarctic Cold Reversal (ACR, between 14.5 and $12.9 \mathrm{ka}$ ). However, new geochronological data are needed to more accurately constrain the evolution of the Copahue volcano presented here.

\section{Declaration of competing interests}

The authors declare that they have no known competing financial interests or personal relationships that could have appeared to influence the work reported in this paper.

\section{Author statement}

All persons who meet authorship criteria are listed as authors and have seen and approved the final version of the manuscript being submitted. They warrant that the article is the authors' original work, hasn't received prior publication and isn't under consideration for publication elsewhere.

\section{Acknowledgements}

This work was supported by Universidad Nacional de Río Negro (project PI UNRN 201740 A 618). We thank Agostina Chiodi and Shanaka de Silva for the English writing assistance, as well as Gerardo Barion and Enzo Martínez for their help during fieldwork. We also acknowledge Jose Luis Macias for editorial handling, and Benjamin Edwards, James Kelly Russell and an anonymous reviewer for their helpful comments that have substantially improved this paper.

\section{Appendix A. Supplementary data}

Supplementary data to this article can be found online at https://doi. org/10.1016/j.jvolgeores.2020.106866.

\section{References}

Balbis, C., Petrinovic, I.A., Guzmán, S., 2016. A contribution to the hazards assessment at Copahue volcano (Argentina-Chile) by facies analysis of a recent pyroclastic density current deposit. J. Volcanol. Geotherm. Res. 327, 288-298. https://doi.org/10.1016/j. jvolgeores.2016.08.009.

Bermúdez, A., Delpino, D., 1999. Erupciones subglaciales y en contacto con hielo en la región volcánica de Copahue, Neuquén. Proceedings XIV Congreso Geológico Argentino. Salta, Argentina. vol. v.2, pp. 250-253.

Cas, R.A.F., Wright, J.V., 1987. Volcanic Successions: Modern and Ancient. Allen \& Unwin, London, p. 528. https://doi.org/10.1007/978-94-009-3167-1.

Caselli, A.T., Velez, M.L., Agusto, M., Liccioli, C., Vaselli, O., 2016a. Prehistoric to historic volcanic activity at Copahue Volcano. In: Tassi, F., Vaselli, O., Caselli, A.T. (Eds.), Copahue Volcano, Active Volcanoes of the World. Springer, Berlin, Heidelberg, pp. 49-59. https://doi.org/10.1007/978-3-662-48005-2_3.

Caselli, A.T., Agusto, M., Velez, M.L., Forte, P., Bengoa, C., Daga, R., Albite, J.M., Capaccioni, B., 2016b. The 2012 eruption. In: Tassi, F., Vaselli, O., Caselli, A.T. (Eds.), Copahue Volcano, Active Volcanoes of the World. Springer, Berlin, Heidelberg, pp. 61-77. https:// doi.org/10.1007/978-3-662-48005-2_4.

Clark, P.U., Dyke, A.S., Shakun, J.D., Carlson, A.E., Clark, J., Wohlfarth, B., Mitrovica, J.X., Hostetler, S.W., McCabe, A.M., 2009. The Last Glacial maximum. Science 325, 710-714. https://doi.org/10.1126/science.1172873.

Cole, R.P., White, J.D.L., Conway, C.E., Leonard, G.S., Townsend, D.B., Pure, L.R., 2018. The glaciovolcanic evolution of an andesitic edifice, south crater, Tongariro volcano, New Zealand. J. Volcanol. Geotherm. Res. 352, 55-77. https://doi.org/10.1016/j. jvolgeores.2017.12.003.

Conway, C.E., Townsend, D.B., Leonard, G.S., Wilson, C.J.N., Calvert, A.T., Gamble, J.A., 2015 Lava-ice interaction on a large composite volcano: a case study from Ruapehu, New Zealand. Bull. Volcanol. 77, 21. https://doi.org/10.1007/s00445-015-0906-2.

Darvill, C.M., Bentley, M.J., Stokes, C.R., Hein, A.S., Rodés, A., 2015. Extensive MIS 3 glaciation in southernmost Patagonia revealed by cosmogenic nuclide dating of outwash sediments. Earth Planet. Sci. Lett. 429, 157-169. https://doi.org/10.1016/j. epsl.2015.07.030.

Darvill, C.M., Bentley, M.J., Stokes, C.R., Shulmeister, J., 2016. The timing and cause of glacial advances in the southern mid-latitudes during the last glacial cycle based on a synthesis of exposure ages from Patagonia and New Zealand. Quat. Sci. Rev. 149, 200-214. https://doi.org/10.1016/j.quascirev.2016.07.024.

Delpino, D., Bermúdez, A., 1993. La actividad del Volcán Copahue durante 1992. Erupción con emisiones de azufre piroclástico. Provincia del Neuquén - Argentina. Proceedings XII Congreso Geológico Argentino. Mendoza, Argentina. vol. v.4, pp. 292-301.

Denton, G.H., Lowell, T.V., Heusser, C.J., Schlüchter, C., Andersen, B.G., Heusser, L.E., Moreno, P.I., Marchant, D.R., 1999. Geomorphology, stratigraphy, and radiocarbon chronology of Llanquihue drift in the area of the southern lake district, Seno Reloncaví, and Isla Grande de Chiloé, Chile. Geografiska Annaler: Series A, Physical Geography 81A, 167-229. https://doi.org/10.1111/1468-0459.00057.

Dixon, J.E., Filiberto, J.R., Moore, J.G., Hickson, C.J., 2002. Volatiles in basaltic glasses from a subglacial volcano in northern British Columbia (Canada): implications for ice sheet thickness and mantle volatiles. In: Smellie, J.L., Chapman, M.G. (Eds.), Volcano-Ice Interaction on Earth and Mars. Geol. Soc. Spec. Pub. vol. 202, pp. 255-271. https://doi. org/10.1144/GSL.SP.2002.202.01.13 London.

Edwards, B.R., Russell, J.K., 2002. Glacial influences on morphology and eruptive products of Hoodoo Mountain volcano, Canada. In: Smellie, J.L., Chapman, M.G. (Eds.) Volcano-ice Interaction on Earth and Mars. Geol. Soc. Spec. Pub. 202, pp. 179-194. https://doi.org/10.1144/GSL.SP.2002.202.01.09 London.

Edwards, B.R., Skilling, I.P., Cameron, B., Haynes, C., Lloyd, A., Hungerford, H.D., 2009. Evolution of an englacial volcanic ridge: Pillow Ridge tindar, Mount Edziza volcanic complex, NCVP, British Columbia, Canada. J. Volcanol. Geotherm. Res. 185, 5251-5275. https://doi.org/10.1016/j.jvolgeores.2008.11.015.

Edwards, B.R., Russell, J.K., Simpson, K., 2011. Volcanology and petrology of Mathews Tuya, northern British Columbia, Canada: glaciovolcanic constraints on interpretations of the 0.730 Cordilleran paleoclimate. Bull. Volcanol. 73, 479-496. https://doi. org/10.1007/s00445-010-0418-z.

Edwards, B.R., Russell, J.K., Gudmundsson, M.T., 2015. Glaciovolcanism. In: Sigurdsson, H. Houghton, B., Rymer, H., Stix, J., McNutt, S. (Eds.), The Encyclopedia of Volcanoes, 2nd edition Academic Press, San Diego, pp. 377-393. https://doi.org/10.1016/B978-0-12385938-9.00020-1. 
Forbes, A.E.S., Blake, S., McGarvie, D.W., Tuffen, H., 2012. Pseudopillow fracture systems in lavas: Insights into cooling mechanisms and environments from lava flow fractures. J. Volcanol. Geotherm. Res. 245-246, 68-80. https://doi.org/10.1016/j. jvolgeores.2012.07.007.

Forbes, A.E.S., Blake, S., Tuffen, H., 2014a. Entablature: fracture types and mechanisms. Bull. Volcanol. 76, 1-13. https://doi.org/10.1007/s00445-014-0820-z.

Forbes, A.E.S., Blake, S., Tuffen, H., Wilson, A., 2014b. Fractures in a trachyandesitic lava at Öræfajökull, Iceland, used to infer subglacial emplacement in 1727-8 eruption. J. Volcanol. Geotherm. Res. 288, 8-18. https://doi.org/10.1016/j. jvolgeores.2014.10.004.

García, J.L., Kaplan, M.R., Hall, B.L., Schaefer, J.M., Vega, R.M., Schwartz, R., Finkel, R., 2012. Glacier expansion in Southern Patagonia throughout the antarctic cold reversal. Geology 40, 859-862. https://doi.org/10.1130/G33164.1.

González Díaz, E.F., 2003. El englazamiento en la región de la caldera de CaviahueCopahue (Neuquén): su reinterpretación. Rev. Asoc. Geol. Argent. 58 (3), 356-366.

González Díaz, E.F., 2005. Geomorfología de la región del volcán Copahue y sus adyacencias (centro-oeste del Neuquén). Rev. Asoc. Geol. Argent. 60 (1), 72-87.

Graettinger, A.H., McGarvie, D.W., Skilling, I.P., Höskuldsson, A.H., Strand, K., 2019. Iceconfined construction of a large basaltic volcano-Austurfjöllmassif, Askja, Iceland. Bull. Volcanol. 81, 9. https://doi.org/10.1007/s00445-019-1269-X.

Groeber, P., 1925. La región de Copahue y su glaciación diluvial. Revista de la Sociedad Argentina de Estudios Geográficos (GAEA) 1 (3), 92-110.

Harder, M., Russell, J.K., 2007. Basanite glaciovolcanism at Llangorse Mountain, northern British Columbia, Canada. Bull. Volcanol. 69, 329-340. https://doi.org/10.1007/ s00445-006-0078-1.

Hein, A.S., Cogez, A., Darvill, C.M., Mendelova, M., Dunai, T.J., Norton, K., Xu, S., Kaplan, M.R., Christl, M., Rodés, A., 2017. Regional mid-Pleistocene glaciation in central Patagonia. Quat. Sci. Rev. 164, 77-94. https://doi.org/10.1016/j.quascirev.2017.03.023.

Hickson, C.J., 2000. Physical controls and resulting morphological forms of Quaternary icecontact volcanoes in western Canada. Geomorphology 32, 239-261. https://doi.org/ 10.1016/S0169-555X(99)00099-9.

Hulton, N.R.J., Purves, R.S., McCulloch, R.D., Sugden, D.E., Bentley, M.J., 2002. The Last Glacial Maximum and deglaciation in southern South America. Quat. Sci. Rev. 21, 233-241. https://doi.org/10.1016/S0277-3791(01)00103-2.

Irvine, T., Baragar, W.R.A., 1971. A guide to the chemical classification of the common volcanic rocks. Can. J. Earth Sci. 8, 523-548.

Jones, J.G., 1969. Intraglacial volcanoes of the Laugarvatn region, south-west Iceland-1. Q. J. Geol. Soc. Lond. 124, 197-211.

Karátson, D., Telbisz, T., Wörner, G., 2012. Erosion rates and erosion patterns of Neogene to Quaternary stratovolcanoes in the Western Cordillera of the Central Andes: an SRTM DEM based analysis. Geomorphology 139-140, 122-135. https://doi.org/ 10.1016/j.geomorph.2011.10.010.

Kelman, M.C. Russell, J.K., Hickson, C.H., 2002. Effusive intermediate glaciovolcanism in the Garibaldi volcanic belt, southwestern British Columbia, Canada. In: Smellie, J.L. Chapman, M.G. (Eds.), Volcano-ice Interaction on Earth and Mars. Geol. Soc. Spec. Pub. vol. 202, pp. 195-212. https://doi.org/10.1144/GSL.SP.2002.202.01.10 London.

Lachowycz, S.M., Pyle, D.M., Gilbert, J.S., Mather, T.A., Mee, K., Naranjo, J.A., Hobbs, L.K 2015. Glaciovolcanism at Volcán Sollipulli, southern Chile: lithofacies analysis and interpretation. J. Volcanol. Geotherm. Res. 303, 59-78. https://doi.org/10.1016/j jvolgeores.2015.06.021.

Le Bas, M.J., Le Maitre, R.W., Woolley, A.R., 1992. The construction of the total alkali-silica chemical classification of volcanic rocks. Mineral. Petrol. 46, 1-22. https://doi.org/ 10.1007/BF01160698.

Lescinsky, D.T., Fink, J.H., 2000. Lava and ice interaction at stratovolcanoes: use of characteristic features to determine past glacial extents and future volcanic hazards. J. Geophys. Res. 105, 23711-23726. https://doi.org/10.1029/2000JB900214.

Lescinsky, D.T., Sisson, T.W., 1998. Ridge-forming, ice-bounded lava flows at Mount Rainier. Wash. Geol. 26, 351-354. https://doi.org/10.1130/0091-7613(1998)026<0351: RFIBLF> 2.3.CO;2

Linares, E., Ostera, H.A., Mas, L., 1999. Cronología Potasio-Argón del complejo efusivo Copahue-Caviahue, Provincia de Neuquén. Rev. Asoc. Geol. Argent. 54 (3), 240-247.

Lodge, R.W.D., Lescinsky, D.T., 2009. Fracture patterns at lava-ice contacts on Kokostick Butte, OR, and Mazama Ridge, Mount Rainier, WA: implications for flow emplacement and cooling histories. J. Volcanol. Geotherm. Res. 185, 298-310. https://doi. org/10.1016/j.jvolgeores.2008.10.010.

Loughlin, S.C., 2002. Facies analysis of proximal subglacial and proglacial volcaniclastic successions at the Eyjafjallajökull central volcano, southern Iceland. In: Smellie, J.L., Chapman, M.G. (Eds.), Volcano-ice Interaction on Earth and Mars. Geol. Soc. Spec Pub. Vol. 202, London, pp. 149-178. https://doi.org/10.1144/GSL.SP.2002.202.01.08.

Mathews, W.H., 1952. Ice-dammed lavas from Clinker Mountain, southwestern British Columbia. Am. J. Sci. 250, 553-565.

Mathews, W.H., 1958. Geology of the Mount Garibaldi map-area, southwestern British Columbia, Canada: part II. Geomorphology and Quaternary volcanic rocks. Geol. Soc. Am. Bull. 69, 179-198.

McPhie, J., Doyle, M., Allen, R., 1993. Volcanic Textures: A Guide to the Interpretation of Textures in Volcanic Rocks. CODES Key Centre, University of Tasmania, Hobart (196 pp.).

Mee, K. Tuffen, H., Gilbert, J.S., 2006. Snow-contact volcanic facies and their use in determining past eruptive environments at Nevados de Chillán volcano, Chile. Bull. Volcanol. 68, 363-376. https://doi.org/10.1007/s00445-005-0017-6.

Melnick, D., Folguera, A., Ramos, V.A., 2006. Structural control on arc volcanism: the Copahue-Agrio complex, South-Central Andes (37 $50^{\prime}$ S). J. S. Am. Earth Sci. 22 66-88. https://doi.org/10.1016/j.jsames.2006.08.008.

Moorhouse, B.L., White, J.D.L., 2016. Interpreting ambiguous bedforms to distinguish subaerial base surge from subaqueous density current deposits. Depos. Rec. 2, 173-195. https://doi.org/10.1002/dep2.20.
Muñoz Bravo, J., Stern, C.R., Bermudez, A., Delpino, B., Dobbs, M.F., Frey, F.A., 1989. El volcanismo Plio-Cuaternario a través de los $34-39^{\circ} \mathrm{S}$ de los Andes. Rev. Asoc. Geol. Argent. 44 (1-4), 270-286

Owen, J., Tuffen, H., McGarvie, D.W., 2012. Using dissolved H2O in rhyolitic glasses to estimate palaeo-ice thickness during a subglacial eruption at Bláhnúkur (Torfajökull, Iceland). Bull. Volcanol. 74, 1355-1378. https://doi.org/10.1007/s00445-012-0601-5.

Peccerillo, A., Taylor, S.R., 1976. Geochemistry of the Eocene calc-alkaline volcanic rocks from the Kastamonu area, northern Turkey. Contrib. Mineral. Petrol. 58, 63-81. https://doi.org/10.1007/BF00384745.

Pedersen, G.B.M., Grosse, P., 2014. Morphometry of subaerial shield volcanoes and glaciovolcanoes from Reykjanes Peninsula, Iceland: effects of eruption environment. J. Volcanol. Geotherm. Res. 282, 115-133. https://doi.org/10.1016/j. jvolgeores.2014.06.008.

Pesce, A., 1989. Evolución volcano-tectónica del complejo efusivo Copahue-Caviahue y su modelo geotérmico preliminar. Rev. Asoc. Geol. Argent. 44, 307-327.

Petit-Breuilh, M.E., 2004. La historia eruptiva de los volcanes hispanoamericanos (siglos XVI al XX): el modelo chileno. Servicio de Publicaciones, Cabildo Insular de Lanzarote, Huelva (431 pp.).

Petrinovic, I.A., Villarosa, G., D'Elia, L., Guzmán, S.P., Páez, G.N., Outes, V., Manzoni, C., Delménico, A., Balbis, C., Carniel, R., Hernando, I.R., 2014. La erupción del 22 de diciembre de 2012 del volcán Copahue, Neuquén, Argentina: Caracterización del ciclo eruptivo y sus productos. Rev. Asoc. Geol. Argent. 71 (2), 161-173.

Polanco, E., 2003. Evolución del volcán Copahue ( $37^{\circ} 45$ S) Andes del Sur. M.S. Thesis. Universidad Autónoma de México, México D.F.

Pollock, M., Edwards, B.R., Hauksdóttir, S., Alcorn, R., Bowman, L., 2014. Geochemical and lithostratigraphic constraints on the formation of pillow-dominated tindars from Undirhlî̉ar quarry, Reykjanes Peninsula, Southwest Iceland. Lithos 200-201, 317-333. https://doi.org/10.1016/j.lithos.2014.04.023.

Roulleau, E., Tardani, D., Vlastelic, I., Vinet, N., Sanchez, J., Sano, Y., Takahata, N., 2018. Multi-element isotopic evolution of magmatic rocks from Caviahue-Copahue Volcanic complex (Chile-Argentina): Involvement of mature slab recycled materials. Chem. Geol. 476, 370-388. https://doi.org/10.1016/j.chemgeo.2017.11.035.

Russell, J.K., Edwards, B.R., Porritt, L.A., 2013. Pyroclastic passage zones in glaciovolcanic sequences. Nat. Commun. 4, 1788. https://doi.org/10.1038/ncomms2829.

Russell, J.K., Edwards, B.R., Porritt, L., Ryane, C., 2014. Tuyas: a descriptive genetic classification. Quat. Sci. Rev. 87, 70-81. https://doi.org/10.1016/j.quascirev.2014.01.001.

Sagredo, E.A., Kaplan, M.R., Araya, P.S., Lowell, T.V., Aravena, J.C., Moreno, P.I., Kelly, M.A., Schaefer, J.M., 2018. Trans-pacific glacial response to the Antarctic Cold Reversal in the southern mid-latitudes. Quat. Sci. Rev. 188, 160-166. https://doi.org/10.1016/j. quascirev.2018.01.011.

Schopka, H., Guðmundsson, M.T., Tuffen, H., 2006. The formation of Helgafell, southwest Iceland, a monogenetic subglacial hyaloclastite ridge: sedimentology, hydrology and volcano-ice interaction. J. Volcanol. Geotherm. Res. 152, 359-377. https://doi. org/10.1016/j.jvolgeores.2005.11.010.

Skilling, I.P., 1994. Evolution of an englacial volcano: Brown Bluff, Antarctica. Bull. Volcanol. 56, 573-591. https://doi.org/10.1007/BF00302837.

Skilling, I.P., 2002. Basaltic pahoehoe lava-fed deltas: large-scale characteristics, clast generation, emplacement processes and environmental discrimination. In: Smellie, J.L., Chapman, M.G. (Eds.), Volcano-ice Interaction on Earth and Mars. Geol. Soc. Spec. Pub vol. 202, pp. 91-113. https://doi.org/10.1144/GSL.SP.2002.202.01.06 London.

Skilling, I.P., 2009. Subglacial to emergent basaltic volcanism at Hlöðufell, south-West Iceland: a history of ice-confinement. J. Volcanol. Geotherm. Res. 185, 276-289. https://doi.org/10.1016/j.jvolgeores.2009.05.023.

Smellie, J.L., 2000. Subglacial eruptions. In: Sigurdsson, H. (Ed.), Encyclopaedia of Volcanoes. Academic Press, San Diego, pp. 403-418.

Smellie, J.L., 2001. Lithofacies architecture and construction of volcanoes erupted in englacial lakes: Icefall Nunatak, Mount Murphy, eastern Marie Byrd Land, Antarctica. In: White, J.D.L., Riggs, N. (Eds.), Volcaniclastic Sedimentation in Lacustrine Settings: Int. Assoc. Sedimentol. Spec. Publ. vol. 30, pp. 9-34. https://doi.org/ 10.1002/9781444304251.ch2.

Smellie, J.L., 2006. The relative importance of supraglacial versus subglacial meltwater escape in basaltic subglacial tuya eruptions: an important unresolved conundrum. Earth-Sci. Rev. 74, 241-268. https://doi.org/10.1016/j.earscirev.2005.09.004.

Smellie, J.L., 2008. Basaltic subglacial sheet-like sequences: evidence for two types with different implications for the inferred thickness of associated ice. Earth-Sci. Rev. 88, 60-80. https://doi.org/10.1016/j.earscirev.2008.01.004.

Smellie, J.L., 2013. Quaternary volcanism: subglacial landform. In: Elias, S.A. (Ed.), Encyclopedia of Quaternary Science, second edition, pp. 780-802. https://doi.org/ 10.1016/B978-0-444-53643-3.00074-1.

Smellie, J.L., Edwards, B.R., 2016. Glaciovolcanism on Earth and Mars: Products, Processes, and Paleoenvironmental Significance. Cambridge University Press, United Kingdom https://doi.org/10.1017/S0954102018000214 (490 pp.).

Smellie, J.L., Skilling, I.P., 1994. Products of subglacial volcanic eruptions under different ice thicknesses: two examples from Antarctica. Sediment. Geol. 91, 115-129. https://doi.org/10.1016/0037-0738(94)90125-2.

Smellie, J.L., Rocchi, S., Armienti, P., 2011. Late Miocene volcanic sequences in northern Victoria Land, Antarctica: products of glaciovolcanic eruptions under different thermal regimes. Bull. Volcanol. 73, 1-25. https://doi.org/10.1007/s00445-010-0399-y.

Spörli, K.B., Rowland, J.V., 2006. 'Column on column' structures as indicators of lava/ice interaction, Ruapehu andesite volcano, New Zealand. J. Volcanol. Geotherm. Res. 157, 294-310. https://doi.org/10.1016/j.jvolgeores.2006.04.004.

Sruoga, P., Consoli, V., 2011a. El Volcán Copahue. In: Leanza, H.A., Arregui, C., Carbone, O., Danieli, J.C., Vallés, J.M. (Eds.), Relatorio del XVIII Congreso Geológico Argentino. Asociación Geológica Argentina, Neuquén, pp. 613-620.

Sruoga, P., Consoli, V., 2011b. Nueva edad $\mathrm{Ar} / \mathrm{Ar}$ para la Formación Las Mellizas. Implicancias en la evolución del complejo Caviahue-Copahue ( $\left.37^{\circ} 51^{\prime} \mathrm{S}, 71^{\circ} 09^{\prime} \mathrm{O}\right)$, 
Provincia de Neuquén. Proceedings XVIII Congreso Geológico Argentino. Neuquén, Argentina. vol. V.10a, pp. 512-513.

Stevenson, J.A., McGarvie, D.W., Smellie, J.L., Gilbert, J.S., 2006. Subglacial and ice-contact volcanism at the Öræfajökull stratovolcano, Iceland. Bull. Volcanol 68, 737-752. https://doi.org/10.1007/s00445-005-0047-0.

Stevenson, J.A., Smellie, J.L., McGarvie, D.W., Gilbert, J.S., Cameron, B.I., 2009. Subglacial intermediate volcanism at Kerlingarfjöll, Iceland: magma-water interactions beneath thick ice. J. Volcanol. Geotherm. Res. 185, 337-351. https://doi.org/10.1016/j. jvolgeores.2008.12.016.

Strelin, J.A., Denton, G.H., Vandergoes, M.J., Ninnemann, U.S., Putnam, A.E., 2011. Radiocarbon chronology of the late-glacial Puerto Bandera moraines, Southern Patagonian Icefield, Argentina. Quat. Sci. Rev. 30, 2551-2569. https://doi.org/10.1016/j. quascirev.2011.05.004.

Tuffen, H., McGarvie, D.W., Gilbert, J.S., Pinkerton, H., 2002. Physical volcanology of a subglacial-to-emergent rhyolitic tuya at Rauðufossafjöll, Torfajökull, Iceland. In: Smellie, J.L., Chapman, M.G. (Eds.), Volcano-ice Interaction on Earth and Mars. Geol. Soc. Spec. Pub. vol. 202, pp. 213-236. https://doi.org/10.1144/GSL. SP.2002.202.01.11 London.
Tuffen, H., Owens, J., Denton, J., 2010. Magma degassing during subglacial eruptions and its use to reconstruct palaeo-ice thickness. Earth-Sci. Rev. 99, 1-18. https://doi.org/ 10.1016/j.earscirev.2010.01.001.

Varekamp, J.C., Maarten deMoor, J., Merrill, M.D., Colvin, A.S., Goss, A.R., Vroon, P.Z. Hilton, D.R., 2006. The geochemistry and isotopic characteristics of the CaviahueCopahue volcanic complex, Province of Neuquén, Argentina. Geological Society of America, Special Paper 407, pp. 317-342. https://doi.org/10.1130/2006.2407(15).

Walker, G.P.L., 1992. Morphometric study of pillow-size spectrum among pillow lavas. Bull. Volcanol. 54, 4590474. https://doi.org/10.1007/BF00301392.

White, J.D.L., Houghton, B.F., 2006. Primary volcaniclastic rocks. Geology 34, 677-680 https://doi.org/10.1130/G22346.1.

White, J.D.L., McPhie, J., Soule, A.S., 2015. Submarine lavas and hyaloclastite. In: Sigurdsson, H., Houghton, B., McNutt, S., Rymer, H., Stix, J. (Eds.), Encyclopedia of Volcanoes, Second ed. Academic Press, pp. 363-375. https://doi.org/10.1016/B978-0-12 385938-9.00019-5.

Zech, J., Terrizzano, C., Veit, H., Zech, R., 2017. Timing and extent of Late Pleistocene glaciation in the arid Central Andes of Argentina and Chile $\left(22^{\circ}-41^{\circ} \mathrm{S}\right)$. Cuadernos de investigación geográfica 43 (2), 697-718. https://doi.org/10.18172/cig.3235. 